\title{
Tax Exemption and Athenian Imperial Politics: The Case of Chalkis
}

\author{
JOSHUA D. SOSIN \\ Duke University
}

SUMMARY: This paper argues that the clause at $I G \mathrm{I}^{3} 40.52-57$, which refers to taxation of aliens at Chalkis and has long puzzled scholars, stipulated that any non-Chalkidian who had been granted immunity from Athenian tele, conditional on residence at Athens or not, should enjoy the same immunity from Chalkidian tele at Chalkis; that the inscription belongs to $424 / 3$ в.C.E, when Athenian law and honorific practice were much concerned with taxation and immunities. Though long seen as fiscal punishment by a newly imperial Athens, the action was connected to later debates about local honors and domestic taxation, and was rather mild.

IG $\mathrm{I}^{3} 40$ PRESERVES TERMS IMPOSED BY ATHENS ON CHALKIS, AND ON ITSELF. THE occasion is thought to be the aftermath of Euboian revolt in $446 / 5$ or else Athenian action against the island in 424/3. ${ }^{1}$ This document is among our richest epigraphic witnesses to what it meant to be on the receiving end of Athenian imperialism. To understand the terms of this settlement is to illuminate not only the "popularity" of the Athenian empire or the "language of Athenian imperialism"2 but also some measure of the legal, political, and

${ }^{1}$ 446/5: Thuc. 1.114; Diod. Sic. 12.7, 12.22.2; Strabo 10.1.3; Plut. Per. 23.3. 424/3: Philochoros FGrH 328 F130 [ $\Sigma$ Ar. Vesp. 718], also F119. Modern debate: Recently, Mattingly 2002 restated and strengthened his case, now more than 50 years old, for redating the text to 424/3, and associating it with the Athenian military action in Euboia mentioned by Philochoros ( $\Sigma$ Ar. Vesp. 718). I have been unable to see a copy of Mattingly 2010a. Rhodes 2008: 504-5 notes that "The settlements with the Euboean cities Eretria, Chalcis and Hestiaea surely belong in 446/5." Papazarkadas 2009: 74 is open to the possibility of the late date. Ostwald 2002: 136: "That the date of the decree is $446 \mathrm{BC}$ is almost universally agreed."

${ }^{2}$ Fornara 1977; Low 2005. 
economic realities of its implementation. The text shows both the tone and actions of empire.

It was resolved that the Athenian council and jurors swear an oath to protect a number of Chalkidian freedoms: from expulsion from Chalkis; from civic devastation; from disfranchisement, exile, arrest, execution, or seizure of assets, without trial; from the introduction of votes against persons without prior and due summons; from undue delay of diplomatic missions; all on condition of Chalkidian obedience to Athens. ${ }^{3}$ The Chalkidians, in turn, are to agree not to revolt, to reject and report anyone who so tries, to pay tribute, to be an upright ally, to aid, defend, and obey Athens; failure to swear is to result in forfeiture of citizen rights and assets alike. ${ }^{4}$

Another decree follows, in which Antikles proposed, apparently at the same session of the assembly (the decree lacks prescript), further: the generals are to see to the expeditious conduct of the oath exchange; the people shall elect five men to administer the oath immediately; a Chalkidian request for action regarding hostages is to be tabled pending future discussion and resolution; certain details concerning taxation of aliens at Chalkis are to be enacted; the decree and oath are to be inscribed at Athens and Chalkis; specific required sacrifices are to be conducted promptly by an appointed panel, which the generals are to oversee, and fund, expeditiously. ${ }^{5}$ To this, Archestratos attached a rider: that Chalkidians retain legal autonomy over euthynai, except in cases where punishment is exile, death, or atimia; that in all such, there shall be ephesis to the heliaia of the thesmothetai at Athens; that Athens's generals are to have oversight of the guarding of Euboia. ${ }^{6}$

If the oath enumerated harsh acts that Athens would forego, the decree and rider that follow indicate intrusions that the imperial city reserved the right to make. But the provision regarding taxation ${ }^{7}$ of aliens confounds ( $I G$ $\left.I^{3} 40.52-57\right)$ :

${ }^{3} I G I^{3} 40.4-16$.

${ }^{4} I G I^{3} 40.21-36$. The terms could have been worse. When Euboia revolted in 446/5 Athens cleared and appropriated Histiaia and "arranged the rest of the island by agree-

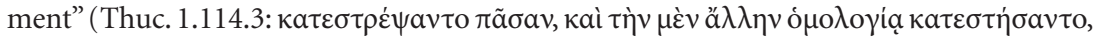

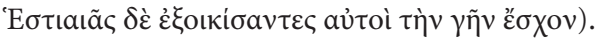

${ }^{5} I G \mathrm{I}^{3} 40.43-69$.

${ }^{6} I G \mathrm{I}^{3} 40.71-79$.

${ }^{7}$ For convenience I shall use "tax," "taxation" and similar to refer to the wide range of

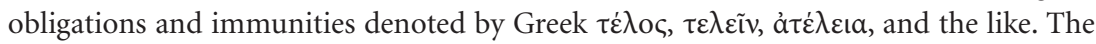
precise meaning of the words in this text is discussed below. 
tòc $\delta$ -

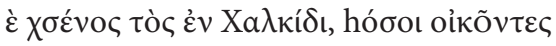

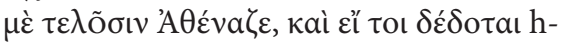

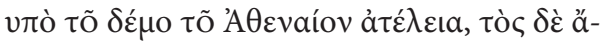

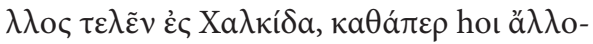

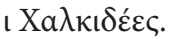

The nature and objective of these provisions is a mystery. Were these aliens Athenian citizens? Cleruchs? Metics at Athens, at Chalkis? Citizens of states allied with or subject to Athens? Merchants? Did the clauses restrict or protect Chalkis's right to tax? If the former, was the measure mild or punitive? Were these tele liturgies, transit taxes, metoikion, tribute, sales tax, or something else? The stakes are high: the passage smells like policy and so affects our understanding of Athens's legal and economic posture in an important period. ${ }^{8}$ Moreover, the passage's grammar is as difficult to unlock as its historical significance and has exercised nearly all who have studied the text. ${ }^{9}$ On the basis of syntactical parallels - two observed already-I propose a new interpretation of what the grammar denotes and, based on that, a new historical understanding of the clauses.

Let us begin with the Greek. Meyer translated, "Die Fremden in Chalkis, welche dort als Metoeken wohnen und nicht nach Athen Steuern zahlen, und wenn Jemandem vom athenischen Demos Steuerfreiheit gegeben ist,—alle anderen sollen nach Chalkis steuern wie die Chalkidier." ${ }^{10}$ For him, the relative clause expresses exception (not "those who do not" but "except those who do") and confers the same on the protasis that follows ("and except anyone to whom

${ }^{8}$ One may find thoughtful review of past scholarship, and ongoing debate over both historical and grammatical interpretation, in many excellent discussions from the last generation: Gauthier 1971: 65-67; Whitehead 1976; Fornara 1977; Balcer 1978: 65-71; Pébarthe 1999: 142-46; Giovannini 2000: 61-63, with Pébarthe 2005; Ostwald 2002: 140-41. Thanks to more than a century of hard work on the text, many of the individual claims that I shall make have originated with others, although the grammatical and historical interpretations that they support are new.

${ }^{9}$ Observations that the grammar is awkward but the meaning clear are old and perhaps ought to have raised a red flag; see e.g., Ditt, Syll. ${ }^{2} 17$ p.29n16: "Haec verba structuram enuntiati turbant etsi sententia perspicua est;" von Stern 1916: 631, referring to Kolbe's interepretation of "des grammatisch nicht ganz correct, aber dem Sprachgebrauch nach völlig einwandfrei gebauten Satzes."

${ }^{10}$ Meyer 1899: 147. 
ateleia has been given"); ${ }^{11}$ the aliens were metics at both Athens and Chalkis, and all aliens resident in Chalkis were to pay taxes thereto except (a) those who were also registered as metics at Athens and (b) those to whom Athens had granted tax immunity. ${ }^{12}$ Athenians who settled in Chalkis, Meyer reasoned, were not to be taxed by their new city of residence; and Athens sought by this measure to extend that same immunity to all metics at Athens and recipients of immunity from Athenian taxation. ${ }^{13}$ The grammar underlying this interpretation, if not necessarily the historical conclusions, matured quickly into something of a scholarly consensus, ${ }^{14}$ which "consists of equating ö $\sigma 0$ เ

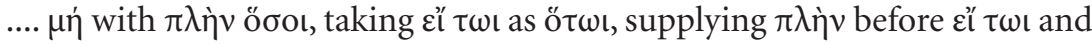

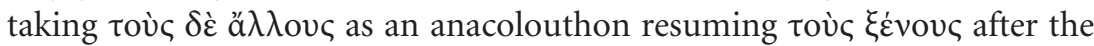
two exceptions have been stated."15 To put it another way: (1) hóбol ... $\mid \mu \grave{\varepsilon}$ $\tau \varepsilon \lambda$ õ

${ }^{11}$ Von Stern 1916: 631-32, expanded: "Die Fremden in Chalkis, welche dort als Metöken wohnen - (es folgt im negativen Nebensatz die erste Einschränkung) sofern sie nicht nach Athen Steuern zahlen und (es folgt im positiven Nebensatz die zweite Einschränkung) wenn jemand vom athenischen Demos Steuerfreiheit verliehen ist-, sie sollen (d. h. alle

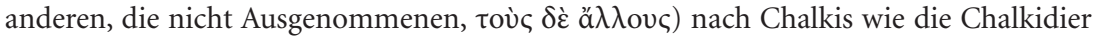
steuern. Daraus folgt, daß von der Steuerzahlung in Chalkis befreit waren: erstens solche Metöken, die in Athen angeschrieben waren und dorthin Steuern zahlten, zweitens die Fremden, denen Athen das Privileg der Steuerfreiheit verliehen hatte." Henry 1979: 288 follows Meyer very closely, observing that the text "may be translated literally as: 'The aliens in Chalcis, as many as living < there > do not pay taxes to Athens, and if to anyone exemption from taxation has been granted by the Athenian demos, the others then (apodotic $\delta \dot{\varepsilon}$ ) shall pay taxes to Chalcis, just as the other Chalcidians $<$ do $>$ '” but that this means that "all the aliens resident in Chalcis shall pay taxes to Chalcis, just as the other Chalcidians do, except in cases where (i) they pay taxes to Athens, or (ii) an individual has been granted exemption from taxation by the Athenian demos."

${ }^{12}$ Kirchner, IG I supp. 27a, emended to achieve the same effect (expressed per Leiden

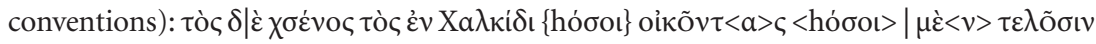

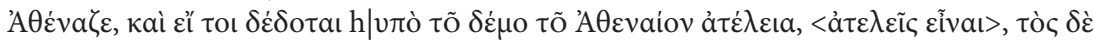

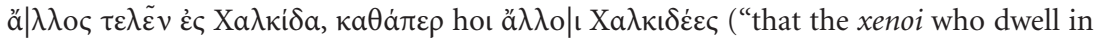
Chalkis, as many as pay tax to Athens, and if ateleia has been granted to anyone by the Athenian people [sc. also they], shall be immune from taxation, but that the others shall pay to Chalkis, just as the other Chalkidians [sc. pay].”)

${ }^{13}$ Meyer 1899: 147.

${ }^{14}$ See, for example, already, Tod, GHI I $\mathrm{p} .86$ : "But the aliens at Chalcis, save those who, resident there, pay taxes to Athens and any one who has received from the Athenian people a grant of exemption, shall in all other cases pay taxes to Chalkis as do also the Chalcidians." Note, however, that Tod's "shall in all other cases" smooths over Meyer's more abruptly literal “—alle anderen sollen;" also Stern's “—, sie sollen (d. h. alle anderen, die ....”

${ }^{15}$ Slings 1977: 277. 


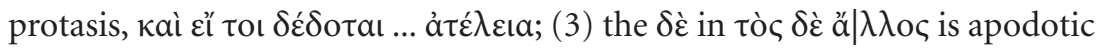

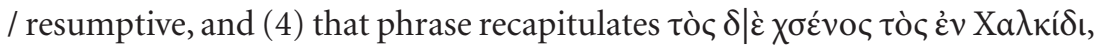
which (5) are in effect also the subject of $\tau \varepsilon \lambda \tilde{\varepsilon} v$.

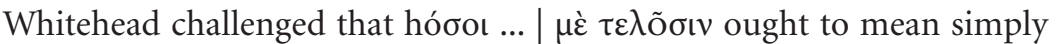
"those who do not pay"; that Vinogradov had rightly understood the resumptive quality of tò $\delta \dot{\varepsilon}$ ă $\mid \lambda \lambda$ oc; that these "others" may have slipped from the reader's or drafter's mind owing to the interruption by the two classes of exceptions. ${ }^{16}$ The "others," then, are not other than the group first mentioned (the aliens), but other than the intervening exceptions. ${ }^{17}$ Whitehead translates, "Those aliens resident in Chalcis who do not pay tax(es) to Athens-including any individual given exemption by the people of Athens-are to pay to Chalcis, just as the other Chalcidians do." 18 On this view, the clauses did not constrain Chalkis's freedom to tax (as Meyer thought), but guaranteed it. Several have followed. ${ }^{19}$ Whitehead was right, I suggest, to try to make sense

${ }_{16}$ Whitehead 1976; Vinogradov 1973.

${ }^{17}$ Thus, Balcer 1978: 71: "The foreigners-the xenoi-living in Chalkis [except those who-while living there pay taxes to Athens (even if they have been given an exemption from taxes by the Athenian people)], these shall pay taxes to Chalkis exactly as do the Chalkidians." Concessive "even if" is dubious; see also Whitehead 1976: 258. This is a

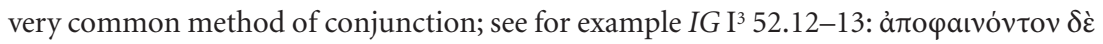

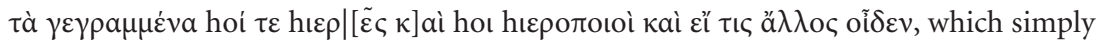
means, "The priests and the hieropoioi and, if anyone else knows (about such documents, he too) shall make the documents known."

${ }^{18}$ Whitehead 1976: 252. Bengtson 1975: 74 no.155 appears to have had suggested something similar: "Die in Chalkis ansässigen Fremden, soweit sie nicht nach Athen Steuern zahlen oder von Athen Steuerfreiheit erhalten haben, sollen nach Chalkis zahlen wie die Chalkidier."

${ }^{19}$ Smart 1977. Fornara 1983: 114, translates, "As to the aliens in Chalcis who are resident there and who are not subject to Athenian taxes, or who have been granted by the People of the Athenians immunity from public burdens (ateleia), they shall pay (taxes) to Chalcis like the other Chalcidians"; this seems to reverse prior agreement with Tod in Fornara 1977: 39. Dillon and Garland 2010: 432: "And the foreigners in Chalkis, who living there do not pay taxes to Athens, or who have been granted exemption from tax by the people of the Athenians, are otherwise to pay tax to Chalkis, just like the other Chalkidians"; a similar formulation occurred already to Lewis 1971: 16; note, however,

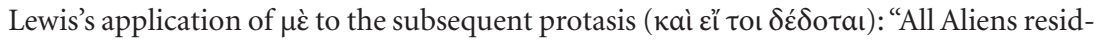
ing in Chalkis who do not pay taxes to Athens and have not been granted tax exemption by the government of Athens, shall pay taxes to Chalkis just like the other Chalkidians." Some, e.g., Koch 1991: 140-41 T4, follow Meyer but treat the resumptive $\delta \varepsilon \dot{~ a s ~ W h i t e h e a d ~}$ does: "Die Xenoi in Chalkis, die dort wohnen, sollen mit Ausnahme derjenigen, die nach Athen abgabenpflichtig sind, und derjenigen, denen von den Athenern Abgabenfreiheit gewährt worden ist, nach Chalkis Abgaben entrichten wie die anderen Chalkidier." 


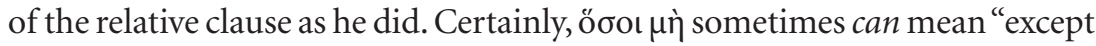
those who do" or "those who do not," more-or-less interchangeably in the same passage, ${ }^{20}$ but this inversion does not always work well, or even at all. ${ }^{21}$ And the resumptive $\delta \dot{\varepsilon}$ is problematic; it appears to be unattested in Greek inscriptions, and on Whitehead's construction, the intervening groups are not distracting exceptions, but the very same xenoi mentioned above.

Against Whitehead, Slings argued for the consensus view, noting that the passage shows the same structure found at Thuc. 5.10.10, which Gauthier had already adduced, and Hdt. 2.77.5 as well. ${ }^{22}$ But in neither passage is the

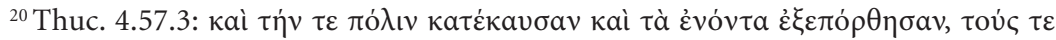
Aỉ

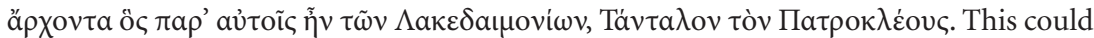
mean, "They torched the city and pillaged its contents, and leading away the Aiginetans who hadn't been killed in the melée they reached Athens ....” Or it could mean, “... and leading away the Aiginetans, except those who had been killed in the melée, they reached Athens ...."

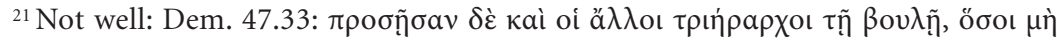

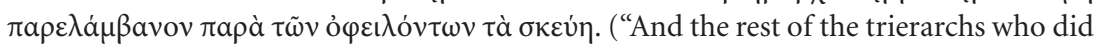
not recover the equipment from those who owed it approached the boule.") Here we could understand "except those who did recover," but not easily, for the speaker's point is that he went to the council, as did all of the other trierarchs who did not recover their materials. Not

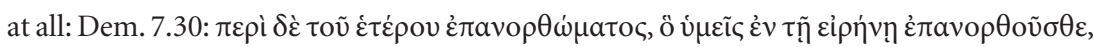

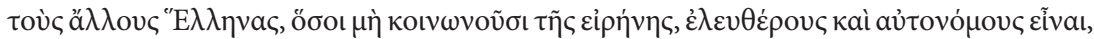

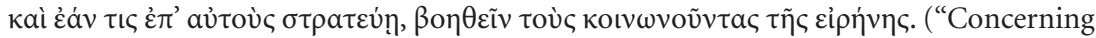
the other amendment that you made in the peace, namely that the rest of the Greeks, who do not share in the peace, shall be free and autonomous, and if anyone campaigns against them, that those who do share in the peace shall bring aid.") This cannot mean "the rest of the Greeks, except those who do share in the peace, shall be free ...."

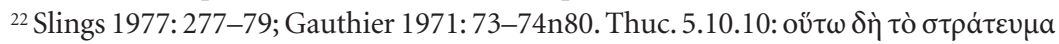

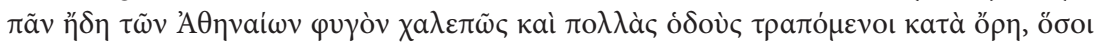

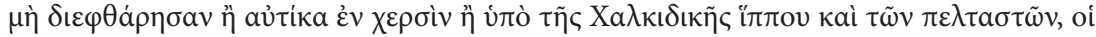

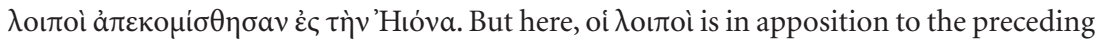
relative clause: "So, the whole Athenian force now being in wretched flight and turning down many paths through the hills, as many as were not destroyed either immediately

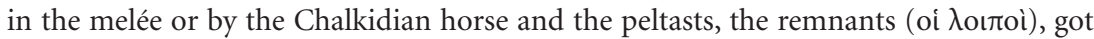
away to Eion." The relative clause interrupts subject and appositive, perhaps a syntactical reflection of tactical disarray. Thucydides used this particular negative qualification

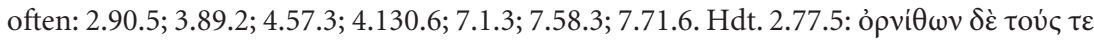

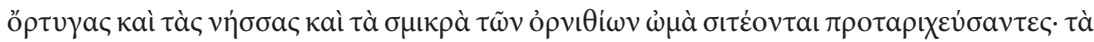

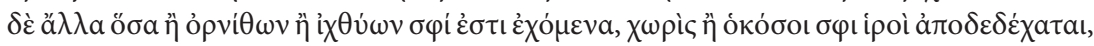

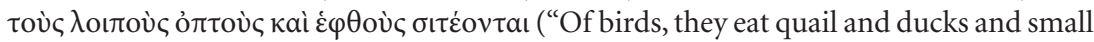
species of little birds raw, after they have pickled them. But as for the rest, as many little birds or fish as they have, except for those acknowledged by them as sacred, the rest they 
"resumed" substantive conjoined with $\delta \dot{\varepsilon}$, as the Athenian decree has. The $\delta \dot{\varepsilon}$ is the puzzle; a parallel without it is not a parallel. ${ }^{23}$

Henry found in Slings's argument "uncontrovertible evidence that Whitehead's translation is impossible" (1979: 287). To Slings's suggestion that the stone's $\Delta \mathrm{E}$ might be $\delta$ ' , he objected that this would have to be supported by epigraphic parallels and that it is "virtually certain" that what we have here

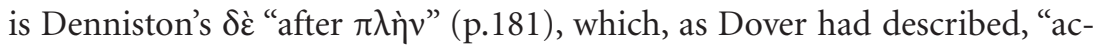
companies 'the rest' after a word-group introduced by 'except."' 24 Apodotic $\delta \dot{\varepsilon}$ itself is an epigraphic rarity. ${ }^{25}$ But this other $\delta \dot{\varepsilon}$ appears to be unattested on stone. ${ }^{26}$ Slings posits that perhaps the "author of the inscription had $\pi \lambda \grave{\eta} v$

eat roasted or boiled.") Here again, we find apposition, and, this time, repetition and a change in gender.

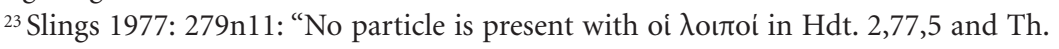
$5,10,10$ and this passage [sc. IG I ${ }^{3} 40.52-53$ ], too, would have been better without it."

${ }^{24}$ Slings 1977: 279n11; Henry 1979: 288; it is certainly $\delta$ : : Dover 1978.

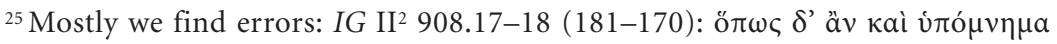

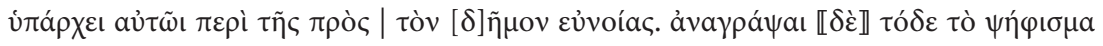
$\tau o ̀ \gamma ~ \gamma \rho \alpha \mu \mu \alpha \tau[\varepsilon \alpha]$; this was an error, erased. The mason may have had the ubiquitous

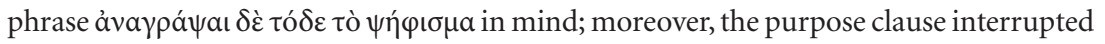
the expected flow of dependent infinitive $+\delta \dot{\varepsilon}$, and this too may have contributed to the appearance of the erroneous $\delta \dot{\varepsilon}$. Similarly SEG XLIX 1503.17-23 (ca.250); I.Priene

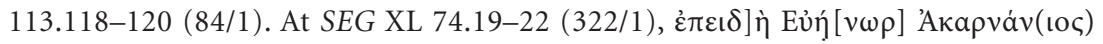

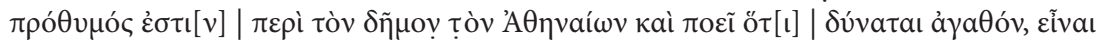

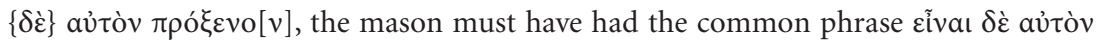

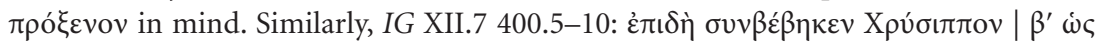

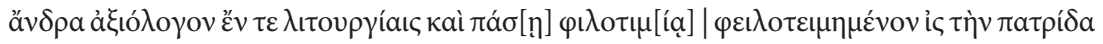

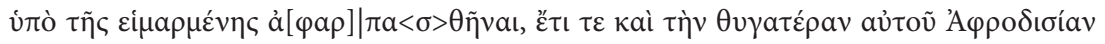

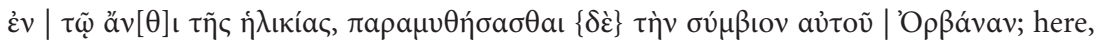
I suspect influence from a pattern common in Amorgan consolation decrees: IG XII.7

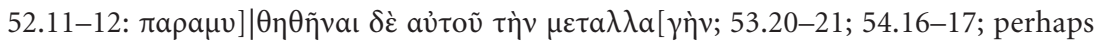
even 239.37-39; 394.20-22; 399.11-12. All of these look like outright errors, not apodotic $\delta \dot{\varepsilon}$. A curse tablet from Olbia perhaps provides firmer ground; SEG XXXVII 673,

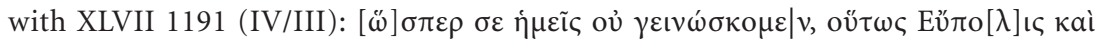

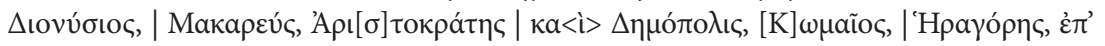

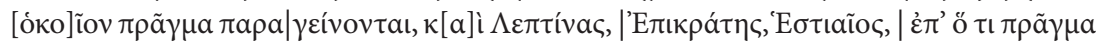

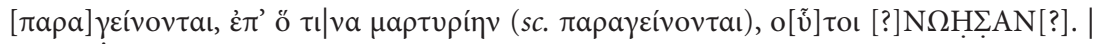

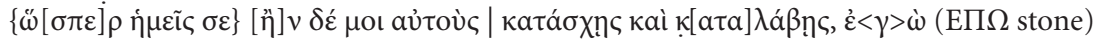

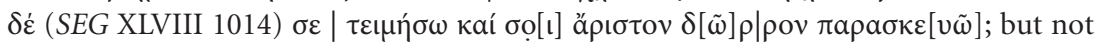
rock-solid: lines 9-11 contain corrupt or unconstrued text; this may be an instance of epigraphic apodotic $\delta \dot{\varepsilon}$ but a clearer case would certainly be welcome. For these instances of likely erroneous—not apodotic — $\delta \dot{\varepsilon}$ I am grateful to Philomen Probert.

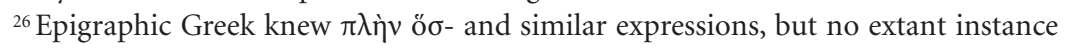
shows trailing apodotic $\delta \dot{\varepsilon}$. Where $\delta \dot{\varepsilon}$ does follow, its use is unexceptional. See, e.g., $I G \mathrm{II}^{2}$ 


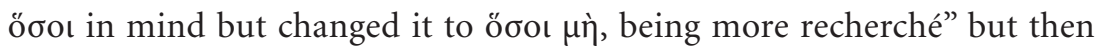
forgot that he had changed his mind so that traces of "the first expression lingered" (1977: 279). In other words, Antikles had a thought, but then had a conflicting thought as a result of an apparent expressive predisposition (the text does not seem otherwise "recherché"), but then forgot that he had had the second thought, so that the phrase for "except" resides not in the text but in a conjectured reconstruction of the cognitive process of composition.

A number of important interpretations as to whom the clauses addressed and what they were meant to accomplish have been advanced on the basis of such understandings of the grammar. Against Gauthier's strong objections that Athens cannot have called Athenians xenoi, Fornara argued that the act was framed in response to a Chalkidian question: "What precisely is to be the status of non-Chalcidians in Chalcis?" and that to this Athens began its reply, "As to your xenoi ...." ${ }^{27}$ This is attractive. But Fornara thinks the first group of aliens at Chalkis was a sizeable population of Athenians who, before the revolt of 446, must have taken advantage of Chalkis's desire to win favor from Athens, and so acquired both egktesis and ownership of significant landholdings, and who subsequently exploited circumstances to secure total immunity from taxation at Chalkis. He concludes that these aliens were-not merely included-Athenian citizens. Thus, the periphrasis designated simply "Athenians resident in Chalkis." That does not seem plausible; the much simpler phrase would have made fine sense in both Athenian and Chalkidian contexts.

Giovannini proposed that the first excepted group represented: (1) Chalkidian metics who may visit Athens for trade and stay long enough to be designated metics there also, and (2) Athenian metics who may visit Chalkis for trade and stay long enough to be called resident, i.e., metics, there also. The purpose of the regulation, he argues, was to prevent either group from becoming liable to liturgies or eisphora simultaneously in two polities (2000: 68-71). Giovannini's second exception could make sense: if Athens had already registered a man as a metic, Chalkis could not do the same, could not levy liturgies or eisphora on him. Athenian metics, by this measure, became a protected class that could not be subject to such taxation in both cities. But on Giovannini's interpretation, a man who was registered as a metic at Chalkis, and who traveled on business to Athens and became registered as a metic there too, would return "home" to Chalkis henceforth to be immune from

244.90-98, 1013.31-33, 1237.88-98; IG VII 3074.2-7; I.Erythrai 9.0-5; Milet I.3 136.17-24; SEG XXVI 72.4-8, XXXIII 143.9-13, XLVIII 1404.37-42.

${ }^{27}$ Fornara 1977: 41; Gauthier, Bull. épigr. 2001: 152, and 1971: 66-67. 
taxation in his city of permanent residence. If a metic at Chalkis wanted to avoid paying taxes, did he need only to relocate to Athens long enough to be registered as a metic, and then to return to Chalkis, thereafter to be immune? This cannot be right. Moreover, the practical hurdles involved with extracting money from an absent metic, who likely owned no real assets in either city, are considerable. ${ }^{28}$ Perhaps more problematic, any non-Chalkidian with a permanent residence in Chalkis (or indeed, anyone, regardless of permanent residence), who found himself required to register as a metic at Athens, would lose that status and its consequent tax liabilities upon leaving Athens; he needed no decree to ensure that. ${ }^{29}$

Ostwald steers a course between Meyer and Whitehead: "The aliens in Chalkis who reside there and fulfill no civic obligations to Athens, except for anyone who has been granted exemption by the Athenian People, must all fulfill their civic obligations to Chalkis, as do all other Chalkidians" (2002: 140). But he understands the decree to say (a) that if one does not pay Athens one shall pay Chalkis, in order to convey (b) that if one does pay Athens one shall not pay Chalkis. On this construction, the relative clause does not state

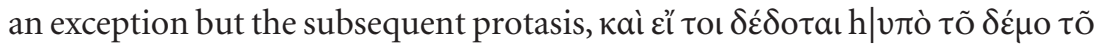

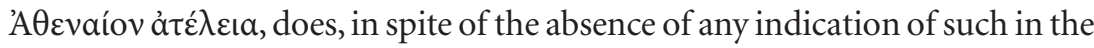
Greek. This does not close the gap between plain reading and interpretation.

Pébarthe has advanced a different understanding of the legal and economic facts, which nevertheless assumes grammar that is quite similar to Whitehead's: "Concernant les étrangers à Chalcis, tous les résidents qui ne paient pas en direction d'Athènes, si une atélie leur a été donnée par le peuple athénien, ceux-là paient alors en direction de Chalcis comme les Chalcidiens." 30 But the

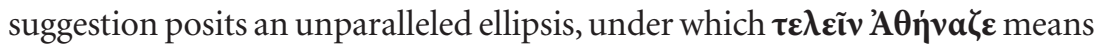
"to pay transit taxes (when/for shipping goods) to Athens." ${ }^{31}$ A solution lying closer to the Greek would be welcome.

One exists, I suggest, in a pair of close grammatical parallels that Wilhelm identified long ago, but did not explain. ${ }^{32}$ Though cited often enough, these have not enjoyed scrutiny by others either. At I.Ilion 1.37-46 (Syll. ${ }^{3} 330$ ), from the late fourth century B.C.E, we read:

${ }^{28}$ Gauthier, Bull. épigr. 2001: 151.

${ }^{29}$ Whitehead 1977: 9: a metic "can stop being one at any time simply by leaving."

${ }^{30}$ See Pébarthe 2005: 90, an interpretation first offered at 1999: 144; same at 2000: 61. Followed by Brun 2005: 41 no.12. Again at Pébarthe 2006: 306.

${ }^{31}$ The clearest parallel for the interpretation is Dem. 32.1, which refers to "contracts to

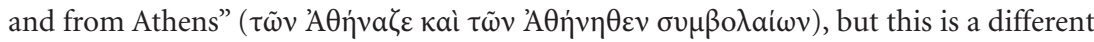
and much less demanding ellipsis.

${ }^{32}$ Wilhelm 1898: 220, and 1942: 126. 


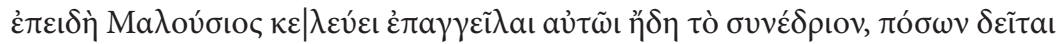

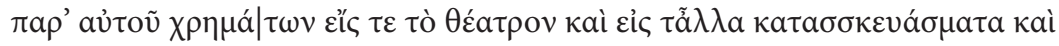

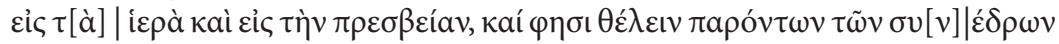

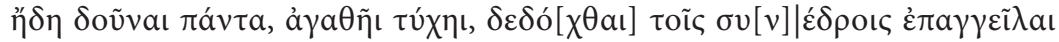

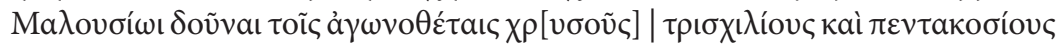

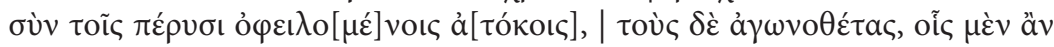

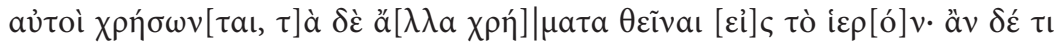

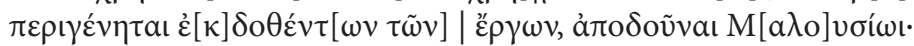

Since Malousios bids the synedrion announce to him forthwith how much money it needs from him, for the theater and for the other constructions and for the sacred things and for the embassy, and (since) he says in the presence of the synedroi that he is willing forthwith to give everything; for good fortune; it has been resolved by the synedroi to ask Malousios to give the agonothetes 3500 gold staters plus the surplus money owed, without interest. That the agonothetes, whatever they need (sc. so much for that), but the remaining money they shall deposit in the sanctuary. If a balance remains, once the works-contracts have been let, (resolved) to return it to Malousios.

Another example appears at P.Cair.Zen. I 59105.1-3 (257 B.C.E):

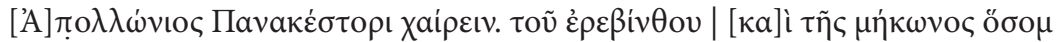

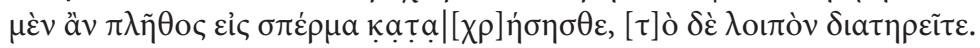

Apollonios to Panakestor, greeting. However much of the chickpea and poppy you have used up already (sc. so much for that), but hold on to the rest.

The editors of the papyrus deemed the Greek ungrammatical. But one could instead see in both a similar ellipsis, ${ }^{33}$ the verbal equivalent of a shrug, more colloquial than formal: "so much for that," or "never mind," or "forget about it."

It appears not to have been noticed that a passage from Antiphon uses the same construction. The speaker is on trial for homicide. His opponents had brought suit against him before, but the Archon Basileus had turned the case away, apparently on grounds that only two months remained to his term, so that the process could not be completed within his magistracy (Antiph. 6.38, 41-42). Then, after the next Basileus took office the speaker's opponents waited more than two months, even while the speaker was engaging in activities from which formal accusation would have barred him (44-45). Anyone else, the speaker argues, would have brought suit as soon as the new Basileus assumed office (45-46):

${ }^{33}$ With the Ilian text Dittenberger, Syll. ${ }^{2} 169$ p.273n7 (retained by Hiller von Gaertringen at Syll. 330 p.550n7) was well at ease: "Apodosis desideratur ex usu notissimo graecorum." 


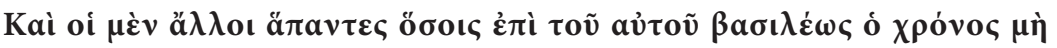

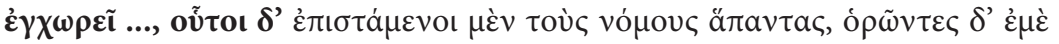

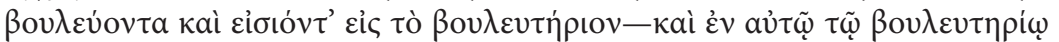

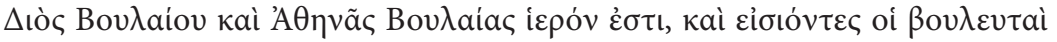

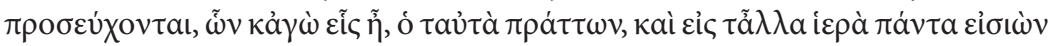

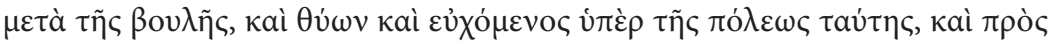

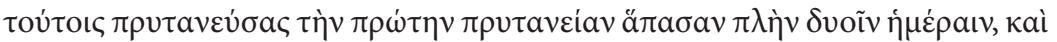

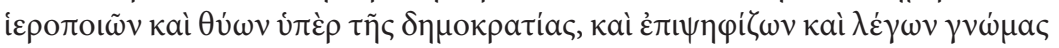

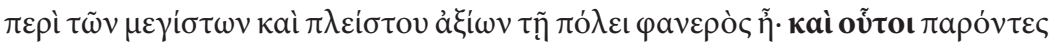

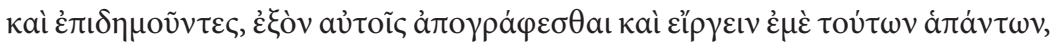

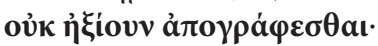

And all other people for whom there is not time (to file suit) during the same Basileus's term (sc. so much for them) - but these men, though they know all of the laws and though they see me serving as a member of the Council and entering the Council house (and in the Council house there is a shrine of Zeus Boulaios and Athena Boulaia, and on entering the councillors pray [there], of whom I too was one, who did the same things, and in entering all the other shrines with the Council, and in sacrificing and praying on behalf of this city, and in addition to these things in having served as prytany the entire first prytany, except for two days, and in serving as hieropoios and sacrificing on behalf of the democracy, and in initiating votes and offering motions concerning the greatest and most valuable matters for the city I was in full public view), yes, these men, though present and in town, though it was possible for them to register and bar me from all of these (activities), never saw fit to register me.

Editors and commentators rightly see an ellipsis at the start of the lengthy sentiment ("All others for whom there is not time-but these ...."). Editors would emend. ${ }^{34}$ I urge instead that Antiphon deployed the same elliptical convention that Wilhelm found in the inscription from Ilion and the Zenon papyrus, and that the Athenian decree on Chalkis did as well:

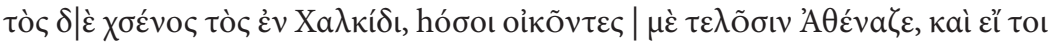

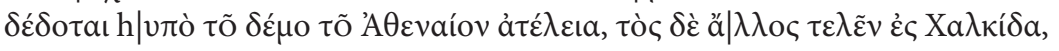

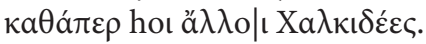

that the xenoi in Chalkis, who, residing (there), do not pay tax to Athens, and if ateleia has been granted to anyone by the Athenian people, (sc. so much for these two groups), but that the others shall pay to Chalkis, just as the other Chalkidians (pay).

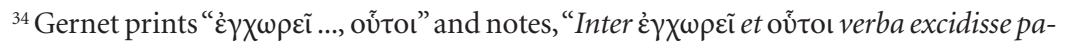
tet," a notional translation of which he supplies: "se hâte de se faire inscrire sous le suivant." 
The Greek does not contain a word or phrase denoting exception, although the particular grammatical construction implies it: "The xenoi of two sorts (sc. so much for them), but the rest shall pay." The $\delta \dot{\varepsilon}$ is not apodotic. ${ }^{35}$ The rela-

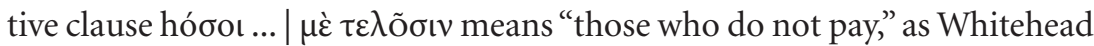

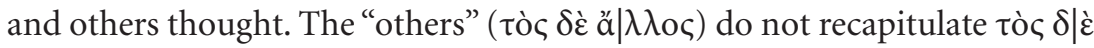

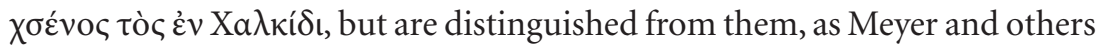
thought. The latter are the subjects of an elliptical verb ( $\mu \grave{\varepsilon} \tau \varepsilon \lambda \tilde{\varepsilon} v$ vel sim.) and the former alone the subject of $\tau \varepsilon \lambda \tilde{\varepsilon} v$. Together, these clauses are meant to confer immunity on two constituent elements of a larger group and liability on the rest. All of this is made explicit in the Greek by an elliptical expression attested in at least two later documents and at least one fifth-century speech.

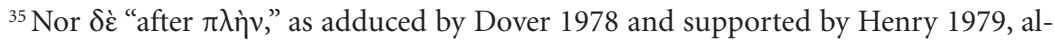
though their instincts were right. No word or phrase for "except" appears, but a logic of exception, under the different construction, which Wilhelm appears to have identified, is present. The precise function envisaged by Denniston is unclear. Most of his examples seem elliptical in a manner similar to what we see in $I G \mathrm{I}^{3} 40$ but are also agreeable to a

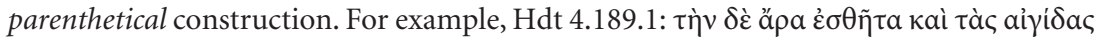

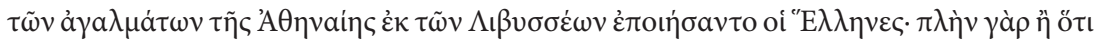

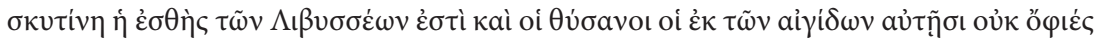

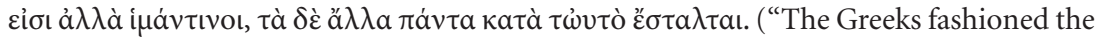
clothing and aegises of Athena's cult statues after the Libyan women's; for except that the clothing of the Libyan women is leather and the tassels [that hang] from their aegises are not snakes but thongs, [so much for these features] but in all other respects she is outfitted in the same way." Or, parenthetically: "The Greeks fashioned the clothing and aegises of Athena's cult statues after the Libyan women's; for-except that the clothing of the Libyan women is leather and the tassels [that hang] from their aegises are not snakes but thongs, but in all other respects [yes]—she is outfitted in the same way.") At least one of his ex-

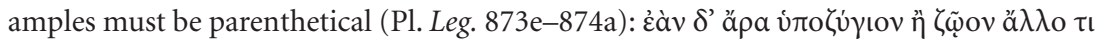

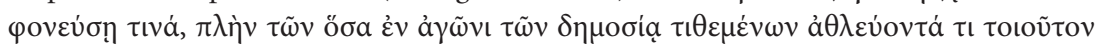

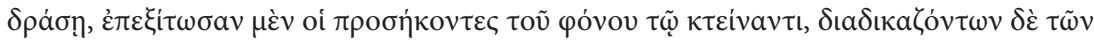

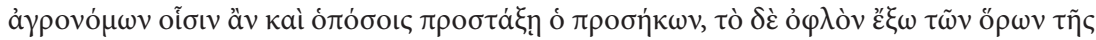

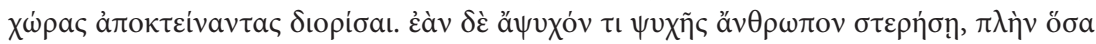

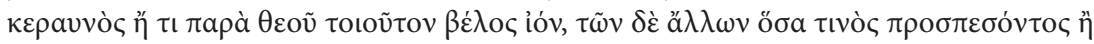

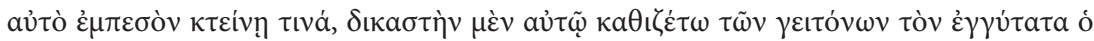

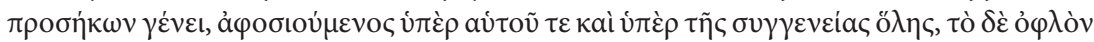

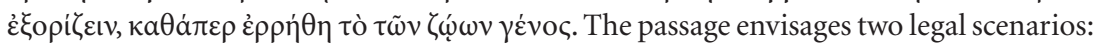
homicide by non-human animal and homicide by inanimate object. In the first case, the

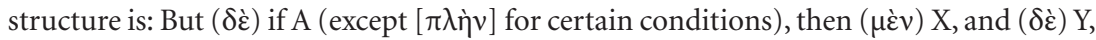

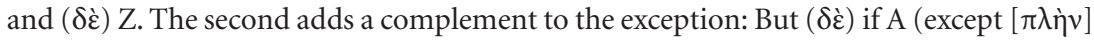
for certain conditions, but [ $\delta \dot{\varepsilon}$ ] [including] the rest), then $(\mu \grave{\varepsilon} v) \mathrm{X}$, and $(\delta \grave{\varepsilon}) \mathrm{Y}$. 
$* * *$

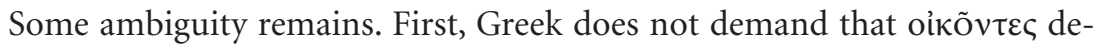
note residence "(in Chalkis)"; it also permits residence in Athens, which no commentator seems to have considered. Next, wherever the aliens lived, the

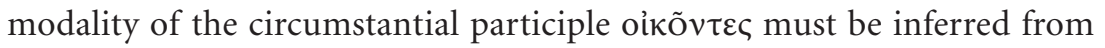
context. ${ }^{36}$ Finally, $\tau \varepsilon \lambda \tilde{o} \sigma \nu v$ could be either indicative ( $\tau \varepsilon \lambda$ oṽ $\left.\sigma v\right)$ or subjunctive $(\tau \varepsilon \lambda \tilde{\omega} \sigma \mathrm{v} v)$. Thus, on the interpretation suggested above and in the light of these further grammatical ambiguities, Antikles proposed "that the xenoi in Chalkis, who, because (/ although / when / if / on condition that) they reside (in Chalkis / in Athens), do not (/ are not to) pay tax to Athens and if ateleia has been granted to anyone by the Athenian people (he too) (so much for these), but that the others shall pay to Chalkis, just as the other Chalkidians (pay)." It appears that no one-at least not in print-has analyzed systematically the possible combinations of modality and place of residence with a view to finding a plausible construction of the rule. Let us do that here. ${ }^{37}$

\section{1.a.i: That Athenians in Chalkis, who although they live in Chalkis do/} shall not pay to Athens, shall not pay Chalkis. On this interpretation, a group of Athenian citizens who resided at Chalkis had previously received immunity from Athenian taxation, and this decree now extended that immunity to apply to Chalkidian taxes as well. This assumes the existence of an otherwise unattested practice under which Athenians residing abroad, or at least at Chalkis, were required to pay taxes to Athens, from afar. Such cannot have applied, say, to sales tax, where the challenge of compliance and enforcement would have been extreme. But if liturgies are meant, as Giovannini argued (2000: 71-74), then the clause enjoined Chalkis from requiring resident Athenians to serve, if those Athenians had already received immunity from the putative requirement to perform liturgies at Athens while residing abroad.

The liability of Athenians resident abroad to Athenian liturgies is not demonstrated. In the better documented period of the 350s B.C.E, we are not certain of the liability even of cleruchs. ${ }^{38}$ And they formed a special class of

${ }^{36}$ Whitehead 1976: 258, urged that it must be "neutral, unemphatic" rather than causal or concessive.

${ }^{37}$ I omit means and manner, which do not give sense. We may exclude the possibility that the taxes at issue were a putative Chalkidian metoikion, for the text cannot have stipulated payment of such to Chalkis "as the other Chalkidians (pay)."

${ }^{38}$ Christ 2006: 151-52 suggests that the difficulty of nominating someone who lived abroad probably meant immunity for cleruchs, in fact if not in law, regardless of the scope of their property at home. See also MacDowell 2004: 127n4. Gabrielsen 1994: 
citizen of whom the state was formally cognizant-and perhaps even of their foreign holdings. ${ }^{39}$ Other Athenians abroad were a different matter.

Against Leptines' law, which barred all but the descendants of Harmodios and Aristogeiton from receiving immunities from liturgical service, Demosthenes argued that to void the ateleia enjoyed by the Bosporan king and honorary Athenian citizen Leukon would be to declare open season on his financial assets. Demosthenes could hardly imagine that anyone nominated to a liturgy would not initiate antidosis against the king! ${ }^{40}$ Leukon would be an easy target, at once rich and unavailable to defend himself in court. ${ }^{41}$

87-90, holds that cleruchs' properties abroad were to be immune from consideration and assessment toward duty, but that "if in possession of sufficient property at Athens"

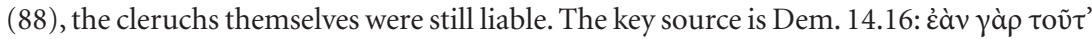

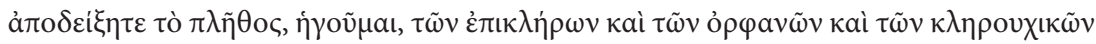

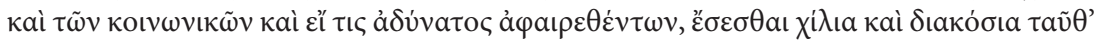
v $\mu \tilde{i} v \sigma \dot{\omega} \mu \alpha \tau \alpha$ ("For if you set this as the number, I reckon-once the epikleroi, orphans, klerouchika, koinonika, and anyone who is incapable are subtracted-you will have twelve hundred individuals"). Orphanoi is a category of persons, whereas klerouchika and koinonika are not; if Demosthenes had meant to indicate that cleruchs were personally immune he would have specified $\kappa \lambda \eta \rho$ oú $\chi \omega \nu$ rather than $\kappa \lambda \eta \rho о v \chi\llcorner\kappa \tilde{v} v$. The two positions need not be mutually exclusive: perhaps the exception of klerouchika referred to cleruchs' holdings abroad, but that foreign residence would have made successful nomination of cleruchs, in most cases, too difficult to be worth the fuss, even if their domestic holdings were sufficient to warrant nomination and they themselves were de iure liable.

${ }^{39}$ For possible records of cleruchic holdings abroad see Morrison 2003: 109-13: IG $\mathrm{I}^{3} 44$ [=Agora XIX L1]; 418 [=Agora XIX L2], the famous list of Euboian temene long thought to have been recorded after the Athenian conquest of $446 / 5 ; 420$. A passage in the Aristotelian Oikonomika mentions eisphora imposed by Athenian cleruchs on the Potidaians, a local initiative: Arist. [Oec.] II 1347a18-24. See van Groningen 1933: 76; Zoeppfel 2006: 20; Thomsen 1964: 41-42. Moggi 1979: 137-42, prefers the fourth century to the fifth. Cargill 1995: 194 suggests that the assessed property here may have included only what cleruchs possessed over and above their kleroi. Christ 2007: 55n8 notes on the basis of this episode "that the eisphora could be levied more broadly within a state"; presumably, this is not meant to suggest imposition by Athens.

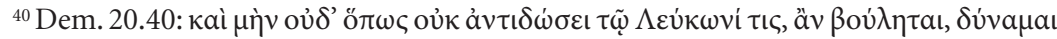

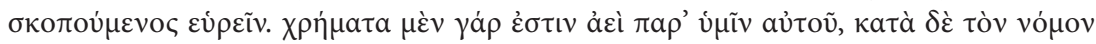

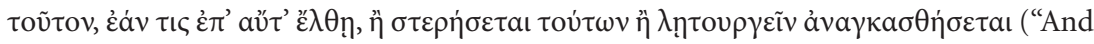
in fact, upon consideration, I cannot see how one would not bring an antidosis challenge

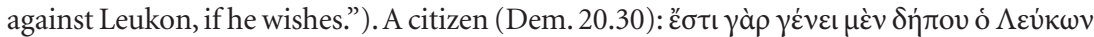

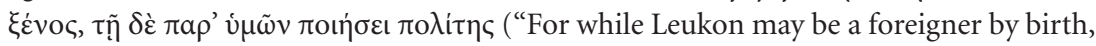
he is a citizen by adoption by you").

${ }^{41}$ Of course, antidosis claims were made largely against visible assets, of which Leukon will not have had many at Athens; Demosthenes speaks of $\chi \rho \eta \dot{\mu} \mu \alpha \alpha$-here, most likely 
But Leukon was a special case and Demosthenes' hypothetical does not demonstrate anything about normal liability. ${ }^{42}$ The difficulty in compelling Athenian citizens resident abroad to serve as, say, choregos probably meant that in practice liability stopped at the border. The logistics of bringing or responding to antidosis claims would have made engagement by Athenians resident abroad a great challenge; they would have had to be present to object to their nomination or else respond to antidosis claims brought against them; they might have had to stay in town for weeks or months during the process of inspection and possible adjudication through diadikasia. ${ }^{43}$ Target selection for proposed antidosis could apparently be strategic, ${ }^{44}$ but we do not read of opportunistic claims brought against Athenians resident abroad, which would have become common if such individuals had been liable. Long-term absentees do not appear to have been called to liturgies.

The fourth century was not the fifth, but, even so, it seems scarcely possible that at the time of $I G \mathrm{I}^{3} 40$ 's passage Athens asserted a right to demand liturgical service from its citizens living abroad.

1.a.ii: That non-Athenians in Chalkis, who although they live in Chalkis do/shall not pay to Athens, shall not pay Chalkis. Under this interpretation, the clause confers on a group of non-Athenians that has already received immunity from Athenian taxation further immunity from Chalkidian taxation. This assumes law under which Athens required non-Athenians resident elsewhere than Athens to pay taxes to Athens. Here again, liturgical service should be the issue. On the face of it, the plausibility of compelling non-Athenians living abroad to perform liturgies for Athens seems quite remote. And yet one litigant appears to claim that his father, a citizen of Mytilene, has served Athens just so (Antiph. 5.77):

money - which will have been invested and invisible. On concealment of assets see Christ 2006: 191-94; Cohen 1992: 191-201; Gabrielsen 1987: 99-114.

${ }^{42}$ Cf. Giovannini 2000: 68: "Comme Leucon ne résidait évidemment pas à Athènes de manière durable, ce texte prouve qu'il n'était même pas nécessaire de résider dans une cité, que ce soit comme citoyen ou comme étranger, pour y être astreint à une liturgie: ce qui était déterminant, c'était d'y avoir des biens, mobiliers ou immobiliers, et c'était sur ces biens, indépendamment de la présence physique de leur propriétaire, que celui-ci pouvait être astreint à une liturgie" [his emphasis]. Kremmydas 2012: 264 notes that "the ateleia conferred on Leukon did not carry any practical benefits for him. Although he was made an Athenian citizen, he was not resident at Athens, [and] therefore he did not have the same responsibilities as 'normal' citizens, i.a. the performance of liturgies, or army service, which were conditioned on residence in Athens."

${ }^{43}$ See Dem. 42 passim on procedure.

${ }^{44}$ See, e.g., Lys. 3.20, 4.1-2; Dem. 28.17; Christ 1990: 147-69. 


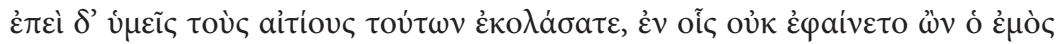

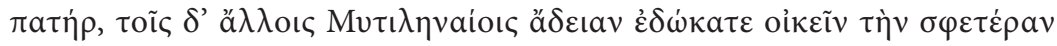

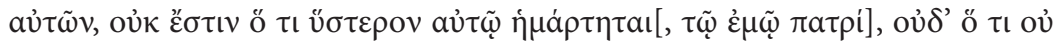

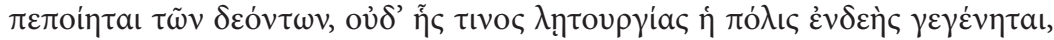

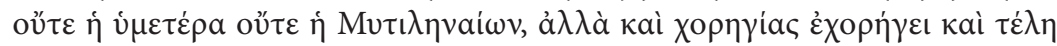
кататіӨฤбเv.

But once you punished those who were guilty of these things [i.e., revolt against Athens], among whom my father was not found to be, and granted to the other Mytilenians the concession to inhabit their own property, there has been no wrong committed by him subsequently, nor anything needed that he has not done, not even any liturgy that the city has needed, neither yours nor the Mytilenians', but he is even in the habit of performing choregiai and he pays tele.

Now, this case is not precisely parallel, since it speaks to the obligations of a subject-city's citizenry, rather than its aliens. But it bears on the liability of non-Athenians living outside Athens. The Greek, though, is opaque. We do not know what the tele were. The choregiai may have been performed at and for Mytilene. ${ }^{45}$ But the speaker seems to assert that his father performed whatever services Athens and Mytilene needed. Perhaps he is dissembling, or implying that to serve Athens's subject is to serve Athens, or that his father had volunteered for some service whose performance law did not compel. Perhaps he speaks of general service and not the narrower set of obligations associated with the word "liturgy." ${ }^{36}$ Perhaps "these services are to be distributed chiastically_khoregiai for Mytilene, taxes for Athens," and perhaps the Athenian convention of proving one's virtue by referring to liturgical service was so powerful that "citizens of subject-states on trial in Athenian courts did their best to conform to it, even if, as is likely in this case, the khoregiai had nothing to do with Athens and $\tau \dot{\varepsilon} \lambda \eta$ was a somewhat flattering term for the 5 per cent flat-rate of imperial tribute or the rents due to the Athenian kleroukhs"; but even so, "[i]t would however be interesting to learn that very rich citizens of subject cities were called on to perform certain khoregiai in Athens." ${ }^{47}$ But if Athens reserved the right to compel foreign subjects to per-

${ }^{45}$ Gagarin 1997: 213.

${ }^{46}$ This does appear to be the earliest use of the term in Attic prose; Lewis 1960: 181, 182 , however, suggests that the word's use in this passage is consistent with classical, fifth-century practice, meaning trierarchy, choregia, gymnasiarchy, etc., and with later, late fifth-/early fourth-century, use, meaning "any service to the community."

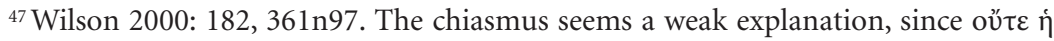

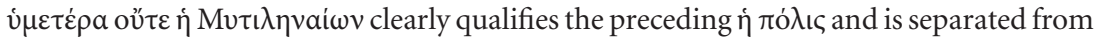

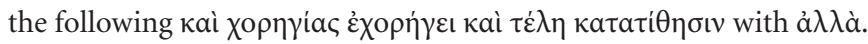


form liturgies at Athens, philotimia alone could not have kept Athenians from routinely bringing antidosis challenges against such vulnerable foreigners. If such a gaping loophole had been available, how many Athenians would have served? This scenario is improbable.

1.b.i: That Athenians in Chalkis, who although they live in Athens do/ shall not pay to Athens, shall not pay Chalkis. This interpretation presupposes an enactment under which certain Athenians who had been granted immunity from taxation at Athens were to enjoy the same protection from Chalkidian taxes. Athenians were on occasion granted immunity from liturgical service. ${ }^{48}$ This construction of the clause is, therefore, possible.

1.b.ii: That non-Athenians in Chalkis, who although they live in $\underline{\underline{A t h e n s}}$ do/shall not pay to Athens, shall not pay Chalkis. On this interpretation, the clause excepted from Chalkidian taxation any alien in Chalkis who had been granted immunity from Athenian taxation even if he should reside in

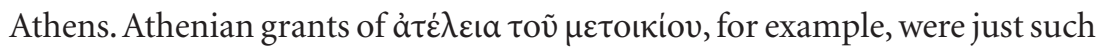
an exception. This interpretation, then, is possible, and also analogous to the exemption that immediately follows (54-55). In both cases, those who by special grant did not pay Athens now could not be made to not pay Chalkis.

2.a.i: That Athenians in Chalkis, who because they live in Chalkis do/shall not pay to Athens, shall not pay Chalkis. On this construction, Athenians who had or would shed liability to Athenian taxation by moving to Chalkis were to be immune to taxation by Chalkis; this would have made Chalkis a taxfree zone for any Athenian who wished to relocate there. This is conceivable.

2.a.ii: That non-Athenians in Chalkis, who because they live in $\underline{\underline{\text { Chalkis }}}$ do/shall not pay to Athens, shall not pay Chalkis. This would have exempted all non-Athenian non-Chalkidians resident at Chalkis from taxation by Chalkis. There is no reason to think Athens would have cared about privileges belonging to those who enjoyed none at Athens. But this is perhaps not inconceivable, as a brutal punishment: it would have barred Chalkis from taxing virtually all metics.

2.b.i: That Athenians in Chalkis, who because they live in Athens do/ shall not pay to Athens, shall not pay Chalkis. This scarcely makes sense. No Athenian was exempt from Athenian taxation because he lived in Athens (unless this is a clumsy way of expressing 1.b.i). This is unlikely.

${ }^{48}$ E.g., Dem. 20.29, 67-87. 
2.b.ii: That non-Athenians in Chalkis, who because they live in Athens do/ shall not pay to Athens, shall not pay Chalkis. As an expression of normative procedure this is nonsense (unless it be a clumsy way of expressing 1.b.ii; as with 2.b.i). This is unlikely.

3.a.i: That Athenians in Chalkis, who when they live in Chalkis do/shall not pay to Athens, shall not pay Chalkis. This is effectively equivalent to 2.a.i above, tax immunity for any Athenian wishing to reside in Chalkis, or else, as 1.a.i above, expresses an exception to an otherwise unattested regulation under which Athenians residing at Chalkis were required to pay taxes to Athens.

3.a.ii: That non-Athenians in Chalkis, who when they live in Chalkis do/ shall not pay to Athens, shall not pay Chalkis. This is effectively equivalent to 2.a.ii above, tax immunity for any non-Athenian, non-Chalkidian wishing to take up residence in Chalkis.

3.b.i: That Athenians in Chalkis, who when they live in Athens do/shall not pay to Athens, shall not pay Chalkis. This means that any Athenian who does not pay taxes to Athens when he lives in Athens shall not pay taxes to Chalkis when he is present in Chalkis. As with 1.b.i above this is a possible interpretation.

3.b.ii: That non-Athenians in Chalkis, who when they live in Athens do/ shall not pay to Athens, shall not pay Chalkis. This scenario is not unlike that of 1.b.ii above, an extension of ateleia in Athens and granted by Athens, so that recipients of this award were able to claim the same exemption in Chalkis. This too is possible.

4.a.i: That Athenians in Chalkis, who if / provided that they live in Chalkis do/shall not pay to Athens, shall not pay Chalkis. This interpretation is plausible only if we assume the existence of an otherwise unattested policy at Athens under which Athenians resident in foreign cities were nevertheless eligible for liturgical service at Athens (see 1.a.i above).

4.a.ii: That non-Athenians in Chalkis, who if / provided that they live in Chalkis do/shall not pay to Athens, shall not pay Chalkis. This is even less likely than the preceding inasmuch as it posits (unattested) policy under which non-Athenians resident outside Athens were liable to Athenian taxation.

4.b.i: That Athenians in Chalkis, who, if/provided that they live in $\underline{\underline{A t h e n s}}$ do/shall not pay to Athens, shall not pay Chalkis. This interpretation is not impossible, as with 1.b.i and 3.b.i above. 
4.b.ii: That non-Athenians in Chalkis, who, if/provided that they live in $\underline{\text { Athens }}$ do/shall not pay to Athens, shall not pay Chalkis. This is essentially the same plausible scenario suggested by interpretations 1.b.ii and 3.b.ii above.

This is a lot to digest. But a couple of facts emerge. First, a great deal rides on the plausibility of 1.a.i, namely the existence of law or convention in accordance with which Athenian citizens resident abroad-or at least in Chalkis-were liable to Athenian liturgical service. There is, so far as I know, no compelling evidence for such law, but if it did exist then IG $\mathrm{I}^{3} 40$ may have extended this immunity to cover Chalkidian taxation as well. If so, then 1.a.i, 3.a.i, and 4.a.i above may be possible interpretations. In the absence of positive evidence, however, it is hard to accept these as probable. If we strike them and the other unlikely candidates, we are left with two basic possibilities.

First, 2.a.i + 2.a.ii, 3.a.ii: That Athenians and non-Athenians in Chalkis, who because they live in Chalkis do/shall not pay to Athens, shall not pay Chalkis; and That non-Athenians in Chalkis, who when they live in Chalkis do/shall not pay to Athens, shall not pay Chalkis. This will have amounted to a brutal curtailment of Chalkis's right to tax aliens within its borders, stipulating that all non-Chalkidians who do not pay taxes to Athens as a result of their residence in Chalkis—in effect, all non-Chalkidians-are to be immune from taxation by Chalkis. Empires do harsh things. But under this interpretation Chalkis could not tax any aliens, so that "the others" ( have existed. Thus, the clauses were not simply meant to confer immunity on any non-Chalkidian who took up residence in Chalkis and therefore was not (or, in case of an Athenian, no longer was) liable to Athenian taxation.

The remaining and, I suggest, correct scenario is 1.b.i\&ii, 3.b.i\&ii, 4.b.i\&ii: That Athenians and non-Athenians in Chalkis, who although / when / if / provided that they live in Athens do/shall not pay to Athens, shall not pay Chalkis. In an argument meant to minimize the ranks of the immune at the time (355 в.C.E), Demosthenes put the number of citizens with ateleia at around five or six, and metics at ten, which must have been low estimates. ${ }^{49}$ In the fourth century, some metics were honored with immunity from Athenian taxation, on condition of residence in Athens. Immunity from the metic tax was inherently conditional ${ }^{50}$ and as a legal fact this might be left unsaid, ${ }^{51}$ for

${ }^{49}$ Dem. 20.21; low estimate: Hagemajer Allen 2003: 204-5. Demosthenes' estimate of the total number of liturgies per year is dramatically low.

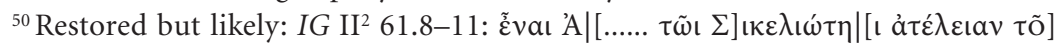

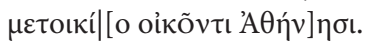

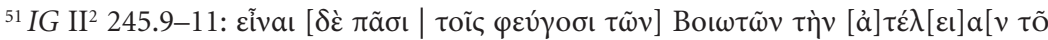

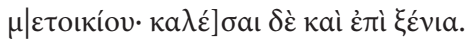


metic status entailed legal residence. Concurrent grants of egktesis and ateleia necessarily recognized a connection between residence and immunity. 52 A number of special grants from the fourth century did as well. In 363/2 Athens decreed citizenship to Astykrates, who along with several others had been exiled from Delphi, their property there having been confiscated (CID II 67-72); to him went ateleia "while" (or "provided that" or "so long as") he resided at Athens. ${ }^{53} \mathrm{~A}$ return to Delphi would end his status, and the immunity. The Akarnanians whom Athens honored in 338/7 were to enjoy egktesis and immunity from the metic tax only until they returned home. ${ }^{54}$ Grants of isoteleia were similarly conditional..$^{55}$ Thus, in fourth-century Athens taximmunity/-equality and residence were tightly related. Conferral of these privileges is less well attested in the fifth century, but it must be stressed that the metoikia itself was both a privilege and an automatic consequence of prolonged presence. ${ }^{56}$ Beyond a month or so, ${ }^{57}$ in the eyes of Athenian law, presence and residence were the same fact. And while the privilege included access to the judicial system, to ritual, and to military service (in all three cases, less than a citizen's but more than a non-metic alien's), what looms largest in the evidence is the "privilege" of contributing the metoikion and, depending on wealth, eisphora and liturgies. A metic was, by definition, an alien who was present long enough to be required to pay his or her fair share of tele. ${ }^{58}$

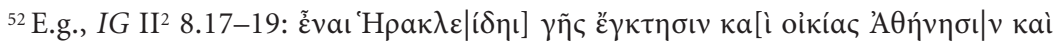

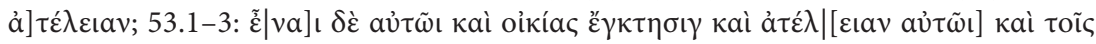

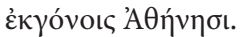

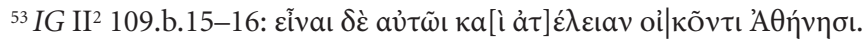

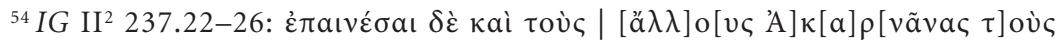

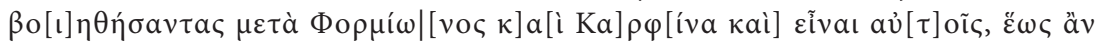

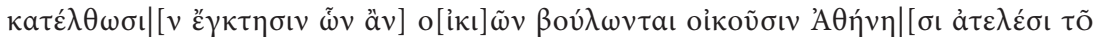
$\mu \varepsilon \tau$ เo $] \kappa\left[i ́\right.$ ov. Similarly, though heavily restored, $I G$ II $^{2}$ 545.8-15 (after 318/17); for other grants to exiles and fugitives see $I G \mathrm{II}^{2} 33.5-8$ (ca. 385); IG $\mathrm{II}^{2} 211.1-15$ (348/7).

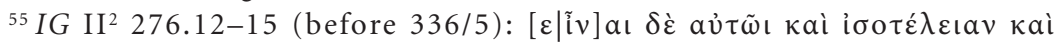

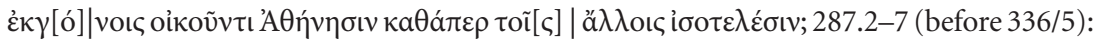

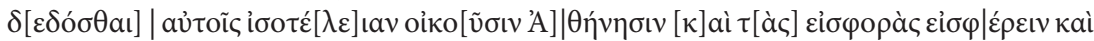

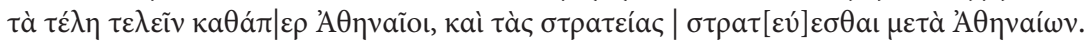

${ }^{56}$ For recent discussion of ordinary and "privileged" metics see Kamen 2013: 43-61.

${ }^{57}$ On duration see Whitehead 1977: 7-10; on terms and definitions 6-20 is fundamental.

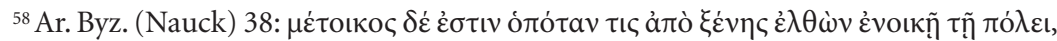

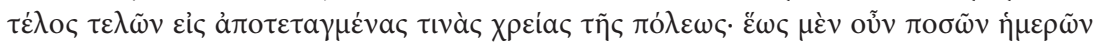

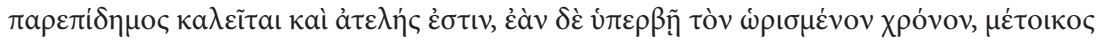

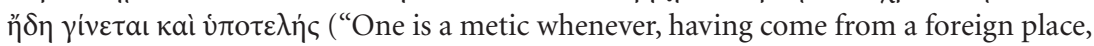


Tax-liability and residence were two sides of a coin. No award of immunity can have been granted, and especially not to a metic, without consideration of its being conditional on residence.

The particular phrasing, which has troubled moderns, arose out of a com-

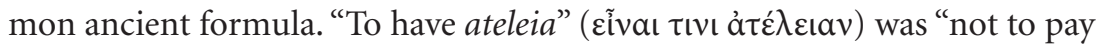

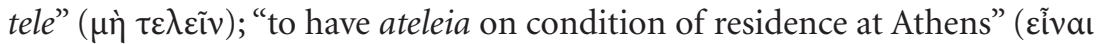

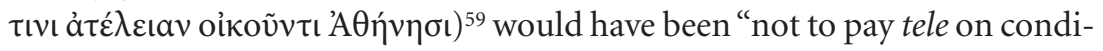

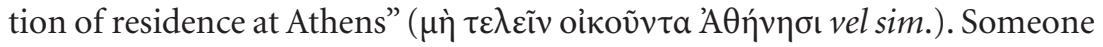

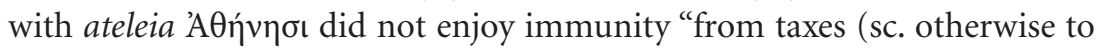
be paid) to Athens," but rather "from taxes while at Athens" 60 ; the lone dative bespoke a condition of presence or, more likely, residence, and was cognate

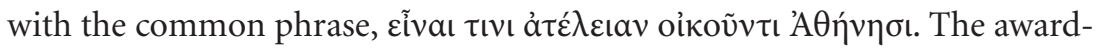
ing of privileges "on condition of residence at Athens" was common in the fourth century, and was inevitably conveyed with a circumstantial parti-

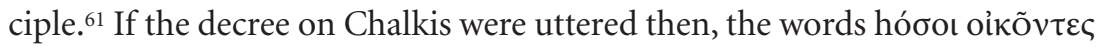

one dwells in the city, paying taxes toward any appointed uses of the city. For up to so many days, then, one is called a 'visitor' and is not liable to the tax, but if one exceeds the designated time, one becomes a metic forthwith and is liable.").

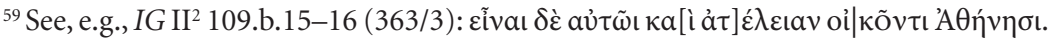

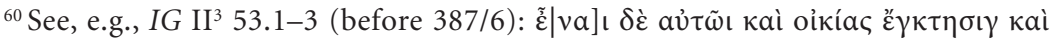

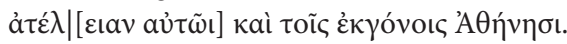

${ }^{61}$ Such bore considerable weight. In the decree on Chalkis, the Athenian oath requires takers to swear fulfillment "for the Chalkidians, provided that they obey the people of

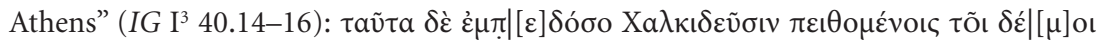

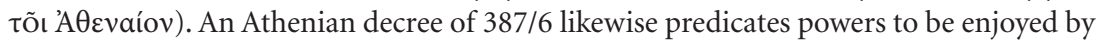
Klazomenai and actions barred to Athens (I.Erythrai/Klazomenai 502.6-13, with SEG LIX 101). An Athenian alliance with Chios promises freedom and autonomy provided that the Chians do not transgress the written terms: IG II ${ }^{2} 34.15-19$ (384/3). Ambiguities around such can be problematic. The second amendment to the United States Constitution begins with an ambiguous participial phrase: "A well regulated militia, being necessary to the security of a free state, the right of the people to keep and bear arms, shall not be infringed." The opinion of the United States Supreme Court in District of Columbia v. Heller, 554 U.S. 570 (2008) p.2-4 (also Syll. 1.a p.1), held that the prefatory (participial) clause indicated purpose and thus did not limit the operative clause that followed; that (p.3) “The Amendment could be rephrased, 'Because a well regulated Militia is necessary to the security of a free State, the right of the people to keep and bear Arms shall not be infringed." And (p.26) the "prefatory clause announces the purpose for which the right was codified: to prevent elimination of the militia." This seems to conflate what antiquity regarded as distinct motives: (1) "in order that X may be the case, $\mathrm{Y}$ is decreed," and (2) "since $\mathrm{X}$ is the case, $\mathrm{Y}$ is decreed." In any case, it is clear that the prefatory clause could not be rephrased, "so long as/provided that a well regulated militia is necessary to the 


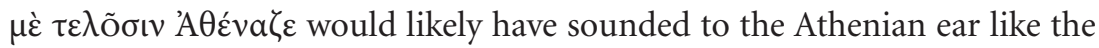

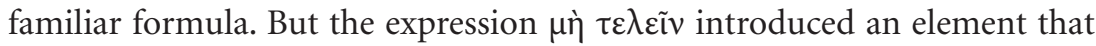
was implicit in Athenian grants of ateleia: the entity to whom payment was (not) offered, here 'A $\theta \varepsilon$ va ${ }_{\varepsilon}$. For an Athenian legislator, articulating the fact of previously awarded immunity, at Athens, as applied to someone who was subsequently at Chalkis, was a task that required more than boilerplate alone.

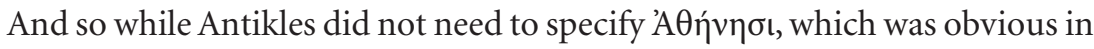
context, formulaic, he had to be very clear that the precondition for immunity at Chalkis was immunity "back at Athens," where aliens covered by the clause had previously resided. And so, rather than a putative fuller expression, hóбoเ

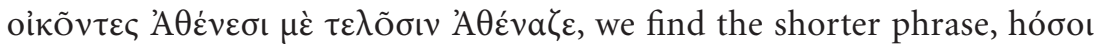

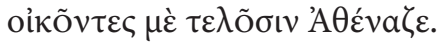

But if the clauses envisage payment at Athens, rather than payment to Athens from a remote location, why stipulate A $A \dot{\varepsilon} v \alpha \zeta \varepsilon$ ? The suffix $-\delta \varepsilon$ does overwhelmingly indicate motion hither in the inscriptions. But not always. Under a provision of Archestratos's rider, Chalkidians were to retain the right of euthyna except in cases where punishment was exile, death, or disfranchise-

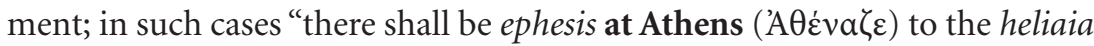
of the Thesmothetai." ${ }^{2}$ The nearly contemporary Eleusinian first fruits decree stipulates "that the demarchs collect deme by deme and hand (the grain) over

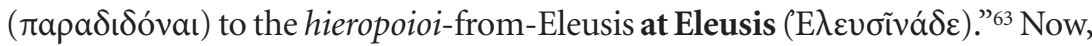
in both cases motion was not explicit in the grammar, but inherent in the realworld process: litigants had to go to Athens in order to bring the case to the heliaia $^{64}$; demarchs had to go to Eleusis in order to deliver the grain. Motion

security of a free state ...."). This would limit the operative clause. For syllabus, opinion, and dissents see: http://www.law.cornell.edu/supct/html/07-290.ZO.html.

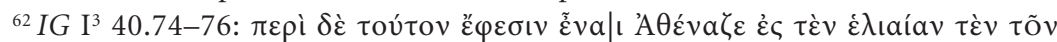

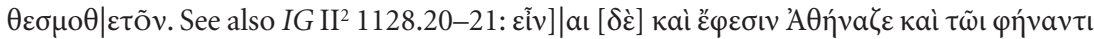

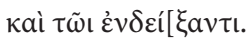

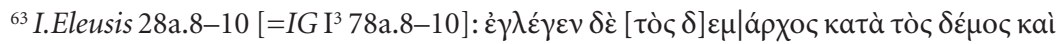

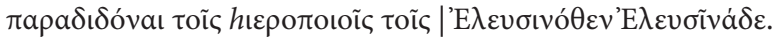

${ }^{64}$ In the case of ephesis, a degree of motion was also inherent in the word's etymology

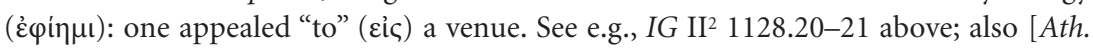

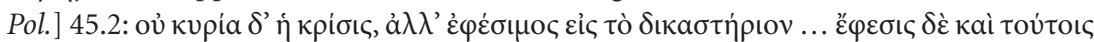

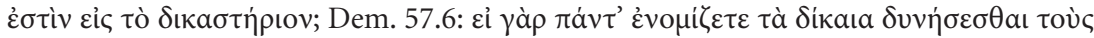

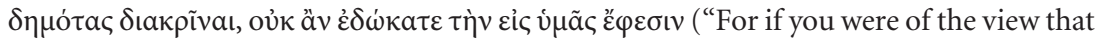
the demesmen could decide all cases justly, you would not have granted the right of appeal to you"). Thus, inasmuch as " $\varepsilon i \varsigma$ + accusative" could be equivalent to the suffix $-\delta \varepsilon$, one could appeal "to Athens to the heliaia." In English one "brings charges," "goes to court," or "takes someone to court" without stressing physical motion. 
was implicit and the suffix indicated location rather than movement. ${ }^{65}$ For the Chalkidian readers of $I G \mathrm{I}^{3} 40$, to contemplate the liability of a person who was in Chalkis, but who had formerly resided in Athens, was to envisage activity in another place and time, "over there," "back at Athens." For an Athenian legislator trying to capture that nuance, 'A $\theta \varepsilon$ va $\zeta_{\varepsilon}$ fit the bill. ${ }^{66}$

Moreover, in an important and apparently unrecognized sense, the clauses explain themselves. The text denotes payment "to Chalkis" with घic. To pay to

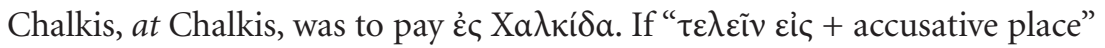
indicates payment to and at, then why write 'A $\theta \dot{\varepsilon} v a \zeta \varepsilon$ rather than $\varepsilon \varsigma$ 'A $A \dot{\varepsilon} v a \varsigma$ ? The short answer seems to be that in early Attic documents one simply did

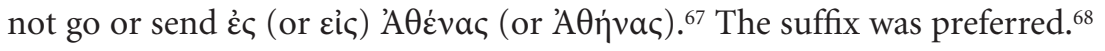

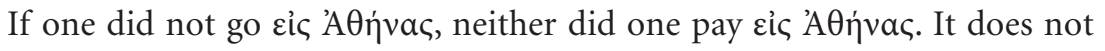
matter that the same decree has Chalkidians swear, "I shall pay tribute unto the Athenians (

${ }^{65}$ An undated Rhodian inscription honored Teleutias for a victory at Olympia (IG XII.1

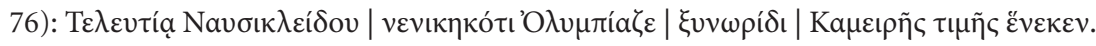
Early in Greek literature, $\dot{\varepsilon} v \theta \dot{\alpha} \delta \varepsilon$ meant here/there rather than (strictly) hither/thither (LSJ

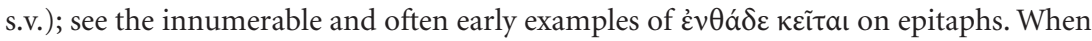
the Bosporan king Satyros came to suspect that the son of his trusted subject Sopaios was conspiring with exiles in Athens, he ordered "those visiting here from Pontos" to seize

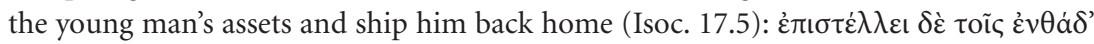

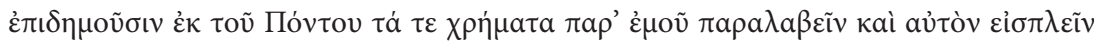

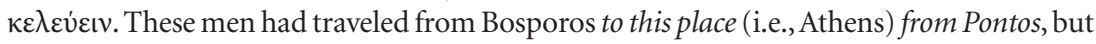
their location, not their prior journey, mattered here. Still, they had gone from Bosporos to Athens as any member of the jury will have understood. See also Men., Georg. 18-19:

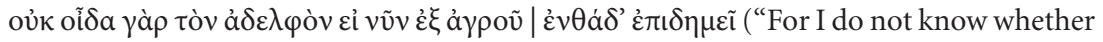
her brother is now here, back from the country"), where the emphasis is presence "here" rather than movement "hither."

${ }^{66}$ Perhaps especially so, if the language was framed in dialogue, as envisaged by Fornara 1977: 41. I owe this observation to N. Papazarkadas, who kindly read an early draft of this paper.

${ }^{67}$ An exception appears to be a funerary poem, where $\dot{\varepsilon} \varsigma$ 'A $\theta$ ńvas fits the meter; this proves nothing, but it stands out as exceptional nonetheless. IG $\mathrm{I}^{3} 1353.4-6$ (ca.445-425

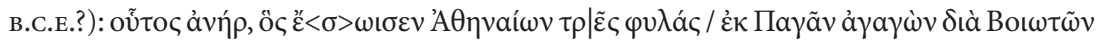

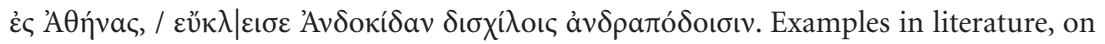
the other hand, are not rare.

${ }^{68}$ For Chalkis, the opposite rule prevailed: nowhere in attested Greek literature did one go or send to Chalkis with $-\delta \varepsilon$, but rather with $\varepsilon$ ic. Andocides claims to have served

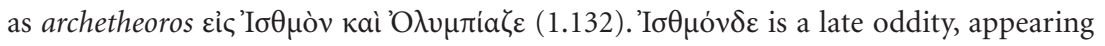

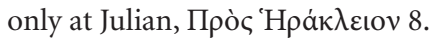




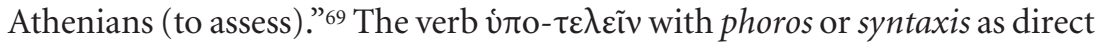
object indicates the payee with the dative, conveying submission of payment

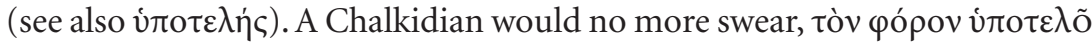
'A $\theta \dot{\varepsilon} v a \zeta \varepsilon$, than a fifth-century Athenian legislator would exempt those who $\tau \varepsilon \lambda$ õ as to pay $\varepsilon i \varsigma$, and neither implied anything about the relative geography of payer and payee.

Finally, this particular provision invokes a prior civic enactment, namely that certain individuals enjoy immunity from Athenian taxation, on condition of residence there. This speaks of compulsion and entitlement, so that $\tau \varepsilon \lambda$ õ $\sigma \nu$ could be subjunctive and not necessarily indicative: those individuals who are not to pay Athens are not to pay Chalkis.

\section{$* * *$}

If these arguments are accepted then the intent of Antikles' provisions was-in sharp contrast to our modern reconstructions - to render both major categories of tax-immunity portable, so that (1) all individuals to whom Athens had granted immunity from Athenian taxation on condition of residence at Athens, along with (2) all to whom Athens had granted immunity that was not so limited, could carry those immunities with them to Chalkis, which would be barred from taxing them. If you were privileged at Athens you were privileged at Chalkis. The clause ensured "that the xenoi in Chalkis, (1) who,

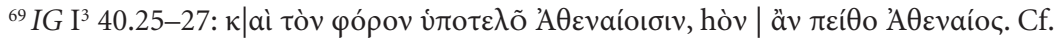

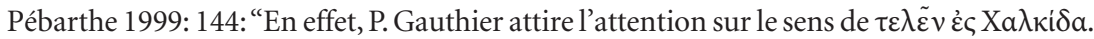
Cette dernière signifie 'payer pour Chalcis' ou bien 'être compté comme Chalcidien' et non pas 'payer à Chalcis.' Mais l'autre formule appelle un commentaire similaire: $\tau \varepsilon \lambda$ õ 'A $\theta \dot{\varepsilon} v a \zeta \varepsilon$ ne saurait se traduire par 'à Athènes' mais par 'vers Athènes'”; and n131: "Lorsque les Chalcidiens prêtent serment ( IG I ${ }^{3} 40.26$ ), ils s'engagent de la manière suivante à propos

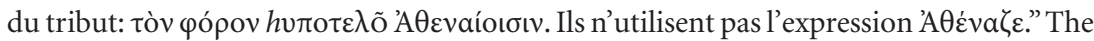
suggestion that $\tau \varepsilon \lambda \tilde{\varepsilon} \nu \dot{\varepsilon} \varsigma$ here indicates "belonging to" goes back, I think, to Dittenberger Syll. ${ }^{2} 17$ p.29n15: "Qui peregrini Chalcide domicilium habent, exceptis Atheniensibus;

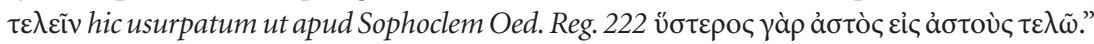
But such different uses of $\tau \varepsilon \lambda \varepsilon \tilde{v} \nu$ so close to each other, the first indicating belonging and the second taxation, would be worrisome. More important, we expect $\tau \varepsilon \lambda \varepsilon \tilde{\varepsilon} v$ to indicate "belonging to Athenians" or "Chalkidians," not to "Athens" or "Chalkis." See examples at

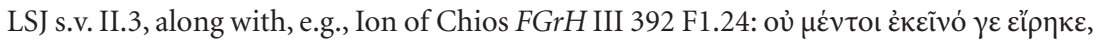

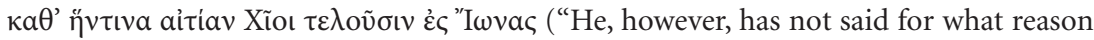
Chians count as Ionians"). Gauthier 1971: 72, suggests that "to pay for Chalkis" and "to be counted as a Chalkidian" are the same historical fact; this good point may be true, but in Greek this use of $\tau \varepsilon \lambda \varepsilon \tilde{\imath} v$ prefers a plural group to a singular composite entity. 
on condition that they reside in Athens, are not to pay tax at Athens, and (2) if ateleia has been granted to anyone by the Athenian people, (sc. so much for these two groups), but that the other aliens shall pay Chalkis, just as the other Chalkidians pay." Why then wasn't the second exemption sufficient to cover all eventualities? Why not stipulate simply that "Those to whom ateleia had been given by the people of Athens" were to be immune from Chalkidian taxation,

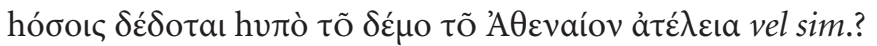

The answer, I suggest, is an Athenian one. There were two basic categories of metic, those who resided at Athens without apparent intention to leave (e.g., Lysias), and transients who resided elsewhere and who were in town on temporary, even if sometimes prolonged, business (e.g., the son of Sopaios, Isoc. 17). Athenian law acknowledged no formal distinction between them. Both were metics and metics had financial obligations. And yet in the world of public honor, there were differences. The rider to the decree according honors to Straton of Sidon stipulated that Sidonians visiting Athens for the purpose of trade could not be saddled with the metoikion, choregia, or eisphora, "provided that they reside in Sidon and are active citizens" there. ${ }^{70}$ Now, they may have been engaged in trade that resulted in their presence in Athens long enough to trigger conversion to metic status. But by this decreed exception, duration of stay ceased to matter, for them; rather, it was their intention to leave-as demonstrated by the purpose of their visit ${ }^{71}$ and their residence and political participation at Sidon-that was decisive. These Sidonians were not barred from remaining in the city beyond the period after which one was required to register as a metic. Rather, Athenians were barred from invoking the duration of their stay as grounds for requiring them to register and so assume liability to metics' financial burdens. Presence was the automatic trigger for liability, but in the determination of immunity residence and intent - in this case "domicile" might be more apt—could be decisive. ${ }^{72}$ Any non-Sidonian merchant whose

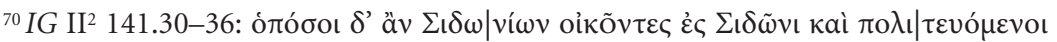

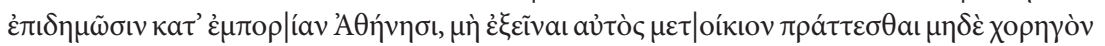

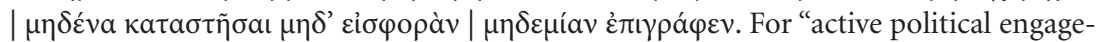

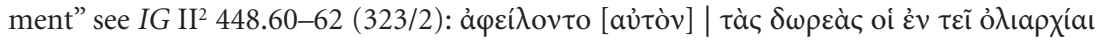

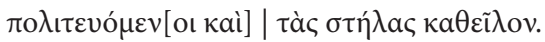

${ }^{71}$ This is itself insufficient proof. The son of Sopaios alleges that he was in Athens "for trade and sight-seeing," and yet he stayed long enough to be made to pay eisphora (Isoc. $17.4,41)$. The danger he found himself in, however, did raise the prospect of his inability to return and, therefore, of a long term stay.

${ }^{72}$ See Giovannini 2000: 69-70 on Roman jurisprudence on domicilium. For the honored Sidonians, even if their stay at Athens exceeded the period beyond which an alien became a metic, both residence in his home state and political participation are stated as requirements for retaining immunity. 
business kept him in Athens long enough would be required to register as a metic, no matter how strong his intention to return to his physical and political home. Such individuals were both visitors, by intent, and residents, in law. ${ }^{73}$ Moreover, Sidonians who relocated to Athens also fell outside the protected class and would have been required to register. Immunities for any of these individuals would likely have been conditioned on residence: so long as they were in Athens, they would be free from the metoikion, eisphora, or whatever, but upon their departure immunity and metic status would die together.

Athenians kept these categories in mind. Against Leptines' law barring all ateleia, except that enjoyed by descendants of Harmodios and Aristogeiton, Demosthenes argued: ${ }^{74}$

Next, gentlemen, by having it written in his law clearly that "no citizen or possessor of tax-equality or alien shall be tax-immune," and by having drawn no distinction as to tax-immunity from which telos-i.e., from the choregia or some other telos-but (by stating) simply that "no one shall be tax-immune except the descendants of Harmodios and Aristogeiton"; and by including all others with the words "no one," while, not distinguishing in the case of the word "metics" those who reside in Athens (sc. from those who do not), he strips Leukon, the ruler of Bosporos, and his sons of the grant that you have given them.

${ }^{73}$ Harpokration distinguishes between a "visiting alien" and a metic who has "es-

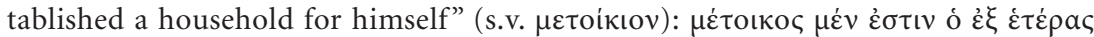

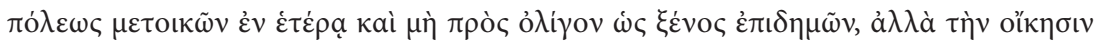

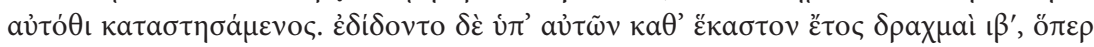

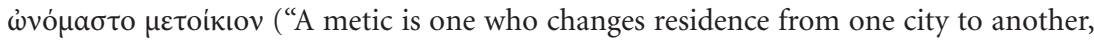
and not briefly visiting as a foreigner but having established residence there. There used to be given by them each year twelve drachmas, which had been called the metoikion"). Jones 2003: 157-60 has shown that the verb $\dot{\varepsilon} \pi ı \delta \eta \mu \varepsilon \tilde{v}$ "almost never" conveys "a notion of residence, and never an implication of time, or of a long or short stay" (157) and is usually best translated as "visit." Legally speaking, Athens could require any visitor to register as a metic, which is to say resident, once s/he had been present on the ground long enough. As Aristophanes of Byzantium framed it, "Whenever (an alien) exceeded the established period (of default ateleia at Athens) he became, forthwith, a metic," which

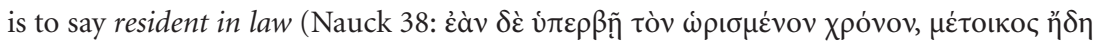

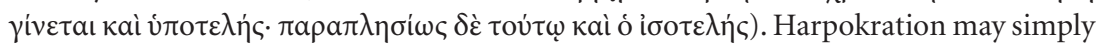
have conflated two senses of "residence," (1) abode and (2) legal status; with passage of time a visiting alien simply became a resident regardless of his abode.

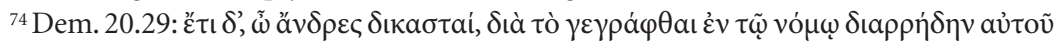

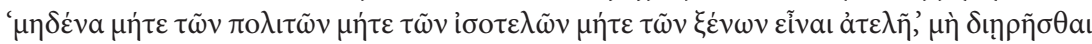

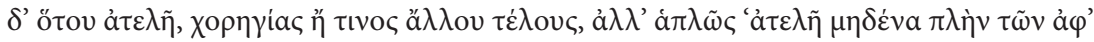

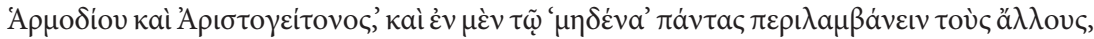

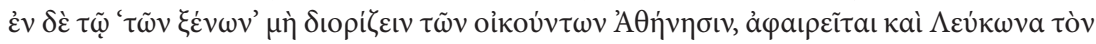

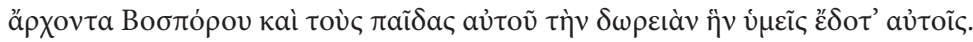


The ban, Demosthenes urges, will offend one of Athens's most important allies. Now, Leukon was a naturalized citizen (Dem. 20.30) and so not subject to rules governing grants to aliens, whether resident at Athens or not. But Demosthenes also seems to object to Leptines' sloppy absolutism, which omits to acknowledge the wide variety of forms and terms that grants of immunity could take, ignores the fact that awards may apply to some tele but not to others, and fails to distinguish immunities that were conditional on residence from those that were not. Such distinctions were important, for as Rubinstein notes, "[d] espite the impression of uniformity given by the bulk of attested ateleia grants, there was considerable variation between individual awards, not just between different communities but even between the grants issued by a single polis." 75

But all recipients will have been either resident or not; all awards will have been conditional on residence or not. When Athenians thought about taxation, whether liability or immunity, they thought about residence. Thus, a proposal to enhance ateleia that was granted on condition of residence might need to answer whether it would exclude holders of simple unqualified ateleia, and a proposal to extend unconditional ateleia might draw cautious requests to specify whether the naked exemption would include grants that were tied to residence. We might have preferred a tidier expression: "All holders of ateleia, whether conditional or not ...." But the Greek as we have it reflects the two basic formats known to Athenian legislation. Now, Antikles granted immunity to both groups, just as Leptines took it from both, but Antikles could not be charged with failing to draw the obvious distinctions. Rather he made it clear that Athens granted immunity at Chalkis to (1) anyone who had received ateleia on condition of Athenian residence, and (2) anyone who had received ateleia that was not limited by any such condition. If Athens liked a person and showed it, Chalkis was required to do the same.

The clause was an infringement on Chalkis's ability to tax aliens within its borders. But which taxes? Telos embraced a lot. ${ }^{76}$ Here, Gauthier thought it denoted tribute; Whitehead and Balcer, an essentially unidentified tax; Vinogradov and Pébarthe, commercial and import/export taxes; Giovannini, liturgies. Ostwald preferred a broader formulation, "civic obligations,"

${ }^{75}$ Rubinstein 2009: 115-16, 120-26, quote at 126.

${ }^{76}$ On telos and other fiscal terminology see Chankowski 2007.

${ }^{77}$ Whitehead 1976: 256; Balcer 1978: 70; Vinogradov 1973; Giovannini 2000; Pébarthe 1999: 142-46 and 2005; Ostwald 2002: 140. On varieties of ateleia see Rubinstein 2009; Henry 1983: 241-61. Of a different time, place, and phenomenon, but invaluable: Gauthier 1991. On Athenian grants of ateleia for "trade-related services" see Engen 2010: 187-92. 
I think. Even in formal utterance Athenians were content to speak simply of tele. When vetting a candidate selected for office the boule asked him, $\tau \dot{\alpha} \tau \dot{\varepsilon} \lambda \eta$ $\left\langle\varepsilon i>\tau \varepsilon \lambda \varepsilon \tilde{\varepsilon}^{78}{ }^{78}\right.$ This was not a fossilized reference to the Solonian tele, nor is it likely to have meant liturgies alone: service was not a prerequisite to office. The question was not ambiguous, but broad, testing whether a candidate "fulfills" what he must. ${ }^{79}$ The clause in the decree on Chalkis was, I suggest, similar in spirit, ${ }^{80}$ not intended to extend one variety of exemption or another, but rather whichever Athens had granted in any given case. If Athens had awarded a person ateleia at Athens from liturgical service, or eisphora, or whatever, ${ }^{81}$ then the same was to apply at Chalkis.

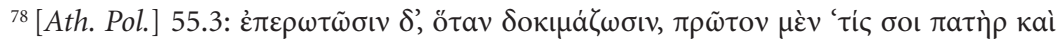

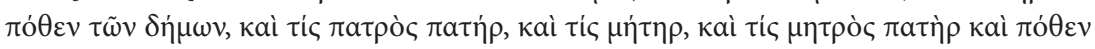

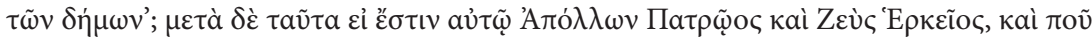

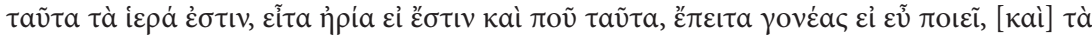

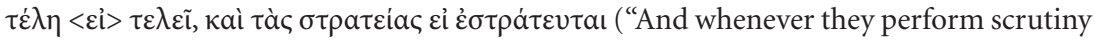
they ask first, "Who is your father and from which deme is he, and who is the father of your father, and who is your mother, and who is the father of your mother and from which deme is he?' Afterward, whether he has an Apollo Patroios and Zeus Herkeios and where these shrines are; next, whether he has family tombs and where these are; then, whether he treats his parents well, and whether he pays his tele and whether he has performed military service").

${ }^{79}$ Rhodes 1993: 618 on [Ath. Pol.] 55.3 observes that Din. 2.17-18 shows that the phrase

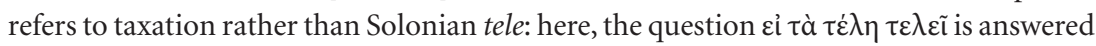

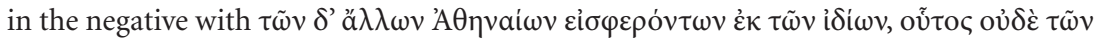

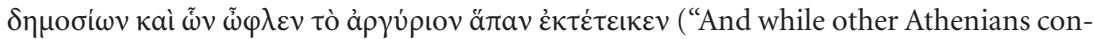
tribute from their own resources, he has not even paid all the money for the public debts that he owed"). Also, citing Onom. 85-86, Rhodes notes that Pollux "or an intermediary must have seen here a reference not to payment of taxes but to membership of a Solonian

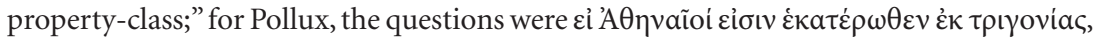

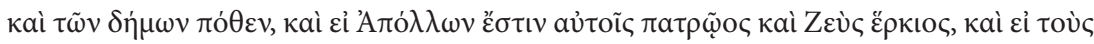

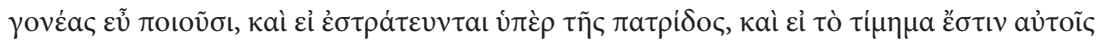
("whether they are Athenians on both sides for three generations back and from which demes, ... whether they have timema"), But if Pollux thought of $\tau$ i $\mu \eta \mu \alpha$ in the sense of "outstanding debt" or "fine" or "payment," so that the question simply asked whether candidates "had any debts (to the polis) outstanding" (but note the definite article, тò), then he need not have thought the question a reference to the Solonian tele at all. His understanding need not have differed much or at all from Dinarchus's.

${ }^{80}$ Similarly, on the broad array of obligations indicated by ateleia see MacDowell 2004.

${ }^{81}$ I assume that such immunities as resulted automatically from service (protections against the burden of back-to-back service) fell outside the intended scope of the clauses. But who knows what a nominee might have found worth arguing in a Chalkidian court? 
The provision will have made it attractive for parties who were honored friends of Athens, whether resident there or not, to engage in business or other activities in Chalkis. Economically, this was a narrower exception than has long been thought. It did not extend immunity at Chalkis to all metics at Athens, but only to individuals who already possessed the benefit at Athens, a much smaller group. The measure did not supersede Chalkis's right to tax aliens on its soil; nor, for that matter, did it prevent Chalkis from granting immunities to anyone it desired. It did, however, allow Athens to declare to certain of its friends that Chalkis was open - to them anyway-for business, at the very agreeable tax rate of zero. ${ }^{82}$ By asserting the right to grant a civic privilege that was to be binding not only in Athens but also in one of its subject cities, Athens infringed not only on Chalkis's fiscal self-determination, but also on its political autonomy. The logic here is nearly identical to that of Archestratos's rider, which introduced a novel ${ }^{83}$ infringement on Chalkis's judicial autonomy: Chalkis was to be free to enjoy the right of euthyna over Chalkidians, except in the most severe cases, over which Athens claimed jurisdiction; all other cases were to proceed as usual (IG I3 40.70-79). So also, Chalkis was to be free to tax as it saw fit, except in the case of one highly visible group, namely those to whom Athens had already granted the privilege of immunity at Athens; all others were to pay taxes as usual. The one provision was a judicial infringement, the other fiscal. Both protected Athens's friends and imperial prerogatives, while curtailing Chalkis's autonomy in particular instances-probably few but certainly high-profile. These interventions were tough but not ruinous, ${ }^{84}$ more likely demeaning than debilitating.

${ }^{82}$ Engen 2010: 188, 189 suggests that Athenian grants of ateleia were economically costly to Athens, but that Demosthenes was right to observe "that the chief benefit of ateleia for its receipients was honorific rather than monetary" (190). This seems to suggest that immunities cost Athens a lot but were worth only a little to the recipients; the opposite ought to have been true. Engen suggests further that grants of ateleia awarded to those engaged in commerce "degraded traditional social values by honoring those who performed trade-related services on par with some of the most highly honored political and military benefactors in Athenian history" (188); also, "the monetary cost" of granting ateleia "for Athens paled in comparison to the deleterious effect that granting it to foreigners for trade-related services would have had on traditional social values" (190). Some Athenians did on occasion show open dislike for those engaged in commerce, but I don't understand the mechanism by which honoring such businessmen "degraded traditional social values," or what that would mean.

${ }^{83}$ Lewis 1992: 131-32.

${ }^{84}$ Forsdyke 2005: 219 argues that the decree on Chalkis shows a moderate, even generous, Athens: "the fact that the Athenian councilors and jurors swore to the Chalcidians 
So much for what the clauses did. When and why? The decree on Chalkis "is almost universally agreed" to belong to $446 / 5$ B.C.E. ${ }^{85}$ The chief reason is that Thucydides and others report that in the same year the Euboians revolted from the Delian League and were swiftly brought to heel by Perikles ( $\mathrm{n} 1$ above). But Mattingly has marshaled an array of evidence to suggest that the document belongs to $424 / 3 .{ }^{86}$ The details are too many and complex to enumerate in their entirety, but some of the salient features are as follows ${ }^{87}$ : Philochoros tells us that Athens campaigned against Euboia in the archonship of Isarchos (424/3). ${ }^{88}$ The Archestratos who proposed the rider at $I G \mathrm{I}^{3} 40.70-80$ could well be identified with the man of the same name who proposed riders at IG I3 73.9-16, 39-44 (ca.424-410). The Hierokles responsible for overseeing sacrifices at $I G \mathrm{I}^{3} 40.64-67$ is very likely the Hierokles attested in Aristophanes (Peace 1047-1119) and Eupolis (Cities 212) and active in the 420s. The legal imposition of Athenian jurisdiction over capital cases arising in subject cities ( $I G$ $\left.\mathrm{I}^{3} 40.71-76\right)$ otherwise seems to be an innovation of the 420 s. The awkwardly proleptic relative clause at $I G \mathrm{I}^{3} 40.45-47$ is paralleled in Attic epigraphy only at $I G \mathrm{I}^{3} 76.30-32(422 / 1)$ and 82.17-18, 29-30 (421/0). Introductory à $\gamma \alpha \theta \tilde{\eta}$

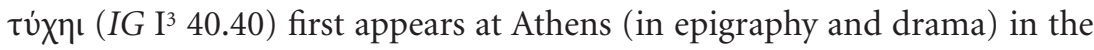
420s. Besides these, Mattingly musters a wealth of circumstantial evidence from fifth-century literature and epigraphy. Moreover, Lawton has observed that acceptance of Mattingly's lower dating for this and three other decrees means that the sculptural form of the Attic document relief is unattested before the 420s, which "would accord well with what we know of sculptural

that all cases of death, exile, and disenfranchisement would be judged by regular legal procedures under the auspices of the Athenian people brings this oath into line with those sworn by these same bodies to the Athenian citizens themselves. Substantively and symbolically, the Athenians therefore placed the Chalcidians on a par with their own citizens, extending to the Chalcidians privileges that were central to their own conception and practice of democratic citizenship."

${ }^{85}$ Ostwald 2002: 136.

${ }^{86} \mathrm{On}$ the impact of his arguments—-with regard to this text and others—-see recently Papazarkadas 2009; Rhodes 2008.

${ }^{87}$ See Mattingly 1961 [=1996: 53-67], with reiterations and enhancements at 2002, 1992; also 1996: 161-62, 247, 372-77, 391-94; recently 2010b, esp. 102-4.

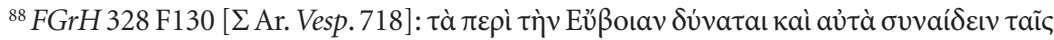

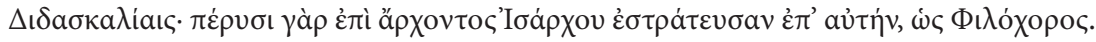
See also FGrH 328 F119. 
practice in Athens at this time." ${ }^{89}$ Knoepfler has added palaeographic support for the later date of the related $I G \mathrm{I}^{3} 39 .{ }^{90}$ Papazarkadas has observed that the leniency of the Chalkidian oath might better reflect an Athenian role as intermediary in an episode of Chalkidian stasis, and that a jibe in Aristophanes (Eq. 236-37) seems to characterize Chalkidians as primed—in 424 в.C.E-for revolt (2009: 73-74).

Why, then, should we prefer 446/5? As Papazarkadas observes, "the major problem in downdating the Chalcis decree was, and continues to be, Thucydides' silence" about the campaign in 424/3. ${ }^{11}$ For Moreno, such an omission would constitute "impossible perversity."

${ }^{89}$ Lawton 1992: 251; Balcer 1978: 84-88, suggested that the stele was accompanied by a relief; Lawton 1992: 249 does not agree: $I G \mathrm{I}^{3} 40$ is absent from Lawton 1995, where her 63 and 64 are now often held to belong to the 420 s.

${ }^{90}$ Knoepfler 2001: 73; finding also in the action of $424 / 3$ a possible explanation for a passage in Pausanias: Bull. épigr. 2011: 314.

${ }^{91}$ Papazarkadas 2009: 74. Though persuaded by many of Mattingly's lower dates and rightly anxious lest an early $I G \mathrm{I}^{3} 40$ become "an isolated case floating in an inscriptional vacuum" (73), he cautions that " $[t]$ here is, however, not much point in isolating specific clauses that might strengthen the lower dating of the Chalcis decree: the process could go on for ever. We can only conclude that an Archidamian War context is not out of the question" (74).

${ }^{92}$ Moreno 2007: 100n114: "One would need to assign impossible perversity to Thucydides in failing to record a large expedition to Euboea, especially given his own clear belief in the island's importance to Athens (esp. in 8.95-6, but elsewhere in his own work from $1.114 \mathrm{on}$ ). The expedition is missing from Thucydides simply because it was relatively minor: it was probably recorded by Philochorus as no more than a reinforcement of the forts securing the island, intended to stem the tide of allied rebellion after Delium and Amphipolis." But Thucydides regarded Euboia's revolt of $446 / 5$ as an opening moment to the war: $1.23 .4 ; 1.87 .6 ; 2.2 .1$. His narrative of 411 suggests that the Euboian revolt of that year was another critical watershed. Athens's democracy was imperiled, and Euboia its last hope; now, revolt there caused terror at Athens that surpassed that generated by the Sicilian disaster(!); Thuc. 8.95.2; 8.95.7-8.96.2 (note the similarity between 8.95.7,

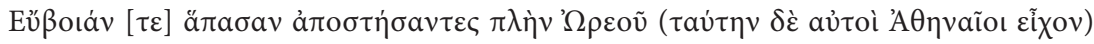

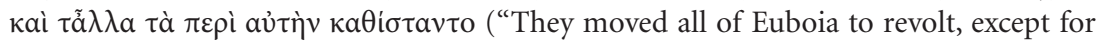
Oreos [the Athenians themselves were occupying it] and they arranged the rest concern-

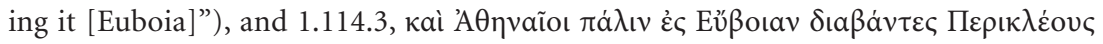

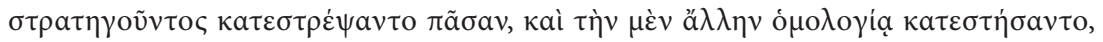

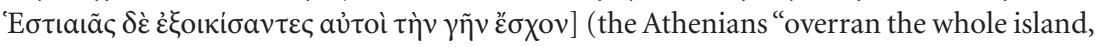
and they arranged the rest under an agreement but after expelling the people of Histiaia occupied the land themselves"). Yet, Athens still managed to dissolve the Four Hundred (8.97.1). An historian keen to frame a narrative bookended by two critical Euboian revolts, one on the eve of war (446/5) and one in 411, might wish to downplay an intervening revolt. Such a wish might not have been "perverse." 
silent about many things, ${ }^{93}$ and his silence here cannot preclude the later date unless it proves that Philochoros was wrong to write of Athens's military action in Euboia in 424/3. But it can do no such thing on its own and no one has found independent cause to reject his testimony. Thucydides' silence was never a compelling argument against the lower date.

If we accept the lower date then we must account for $I G \mathrm{I}^{3} 39$, which preserves a scrap of what looks to be an oath to be taken by Eretrians, which is nearly identical to the one preserved at $I G \mathrm{I}^{3} 40$ and so seems to belong to the same episode. ${ }^{94}$ Though he has tended to date $I G I^{3} 39-41$ together, ${ }^{95}$ Mattingly acknowledged in at least one place that $I G \mathrm{I}^{3} 39$ 's palaeographical similarities to $I G \mathrm{I}^{3} 10$ and 55 mean that it probably ought to fall before the Archidamian War. ${ }^{96}$ Jameson, however, put $I G \mathrm{I}^{3} 10$ "not much earlier than $420,{ }^{\prime 97}$ and Knoepfler has shown that 39 is in fact palaeographically at home in the last

${ }^{93}$ One need not accept all of the arguments advanced by Badian 1993 to appreciate that Thucydides cannot have mentioned all events that we think he ought to have found significant. Thucydides' silence has not kept the late date for $I G I^{3} 21(426 / 5)$ from prevailing: see Mattingly 2010b: 99-100 and 100-102 on Thucydides and the three-barred sigma.

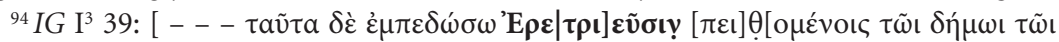

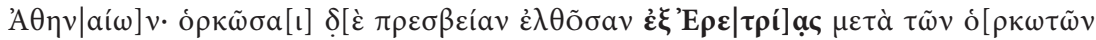

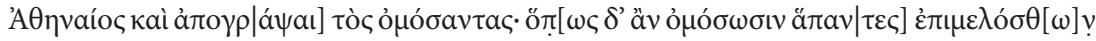

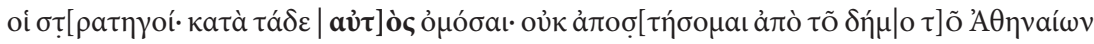

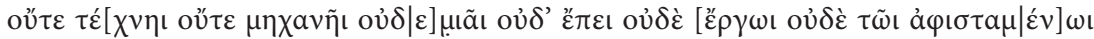

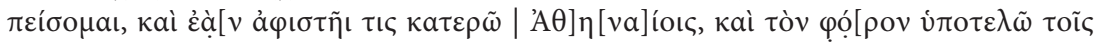

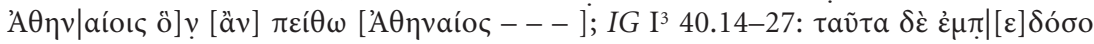

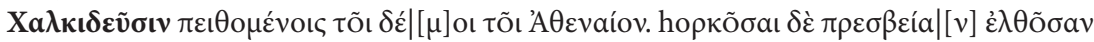

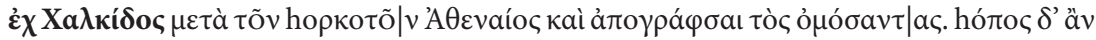
[ỏ]

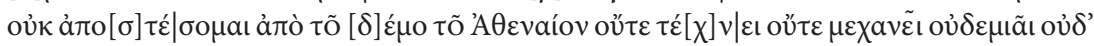

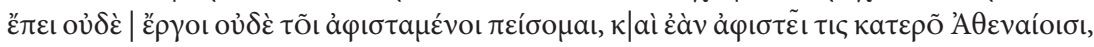

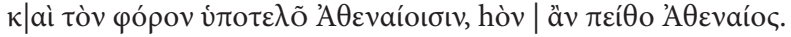

${ }^{95}$ E.g., Mattingly 1996: 162, 176.

${ }^{96}$ Mattingly 1996: 514n39. For the Ionic script in $I G \mathrm{I}^{3} 39$ and several other texts see Low 2005: 104-9, who suggests that "They exemplify a move towards a style of representing an interstate relationship in which the power that is being exercised over the allies is not, straightforwardly, Athenian kratos, reaching out beyond the boundaries of Attica and overtaking everything in its path. What is represented is, instead, a more subtle, homogenizing approach to the construction of power, in which Athens is not so much the enforcer of an Athenian way of life as a facilitator of some wider, perhaps Panhellenic, relationship" (108). On Ionic script see recently Matthaiou 2010: 13-18.

${ }^{97}$ Jameson 2000-3: 29. 
quarter of the fifth century. ${ }^{98}$ As for the very poorly preserved provisions for Histiaia ( $I G \mathrm{I}^{3} 41$ ), perhaps they seem better suited to Athens's assumption of control in 446/5, but they could belong to either time. Anyway, whatever the date of $I G \mathrm{I}^{3} 39$ and 41 (and I am inclined to keep them together with 40, and all three late), in 424/3 Euboia was a piece of unfinished business for Athens.

In fact, it was a recurring challenge, almost as old as Athens's democracy. In 506 B.C.E, in retribution for an assault on Attica, Athens met and defeated the Boiotians on their side of the Euripos and crossed over to Euboia, where they bested the Chalkidians too and left behind 4000 cleruchs on the land of the wealthy hippobotai. They bound and ransomed the captives, and then dedicated the chains on the Acropolis. With a tenth of the ransom Athens commissioned and dedicated a tethrippon on the Acropolis, on the left as one approached the propylaia, accompanied, Herodotus tells us, by an epigram (Hdt. 5.77.2-4.). We know the epigram also from two inscribed copies, one thought to have been produced with the monument shortly after 506 , the

${ }^{98}$ Knoepfler 2001: 73. It may be worth observing that the sole internal indication that $I G \mathrm{I}^{3} 39$ concerns Eretria per se is a single doubtfully read letter, the alpha at the start of

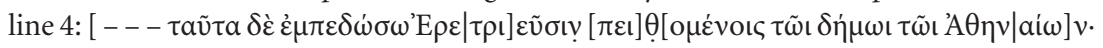

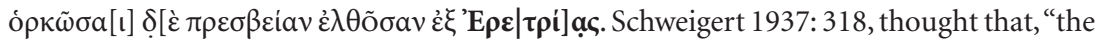
fracture of the left edge of the fragment near line 4 clearly follows the right hasta of a letter like $\mathrm{A}, \Lambda$, or $\Delta$. . Neither the photograph accompanying his publication, nor the image at Low 2005: pl.5, nor the squeeze taken by Balcer, now at Ohio State University (http:// drc.ohiolink.edu/bitstream/handle/2374.OX/506/IG\%20I\%283\%29\%2039.jpg), nor the squeeze in the collection of the Oxford Centre for the Study of Ancient Documents (a digital image of which C. Crowther has kindly shared with me), appears to show any trace of an alpha, or indeed anything else, before the final sigma in 'E $\rho \varepsilon \mid \tau \rho i]$ ac. This is worrisome. I wonder whether $I G \mathrm{I}^{3} 39$ records an oath taken by a Euboian city on some other occasion;

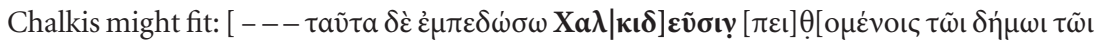

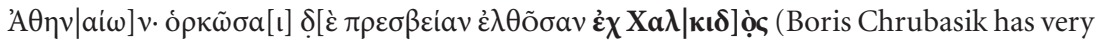
kindly confirmed that his own examination of the CSAD squeeze and the stone itself led him to conclude that an alpha did not precede $\Sigma$ at the start of line 4). But what would this mean? Could it be that $I G \mathrm{I}^{3} 39$ was produced in the aftermath of the Periklean action in $446 / 5$ and IG I $\mathrm{I}^{3} 40$ after that of 424/3, the latter seeking to reaffirm what Athens had already "arranged," introducing some new measures and, at least in the case of hostages,

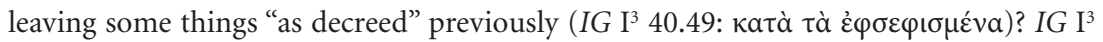
39 would in this case represent an early instance of Ionic script at Athens, but such seem to be known; for a recent, interesting discussion of possible implications see Low 2005: 105-9. The extreme similarity of two oaths separated by more than twenty years inclines me to think not. But in any case, the ground appears to be less stable here than we have thought and it seems safe to say that $I G \mathrm{I}^{3} 39$ might not have contained an oath taken by Eretria, whatever its date. 
other in the mid fifth century ${ }^{99}$ Long after the event, the chains, statue, and epigram reminded all who mounted the acropolis of that occasion on which Athens "extinguished the hybris" of the Boiotians and Chalkidians, even if the Athenians could not, in Aelian's later formulation, "extinguish their anger against Chalkis." ${ }^{100}$ In 446/5, Athens's victory of 50 years prior was still a fresh memory. And two decades later, the events of $446 / 5$ were as well. Whatever the precise causes of action in 424/3, around that time Aristophanes had his mind on Athens's earlier Euboian victory. Bdelykleon laments distributions of Euboian wheat, which were promised but never materialized; instead, Athenians barely got barley, and only if they could prove citizenship! ${ }^{101}$ We know from Philochoros that this was Egyptian barley, delivered the year after the victory over Euboia (whose defeat perhaps wasn't the alimentary bonanza

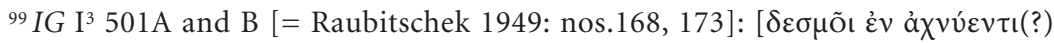

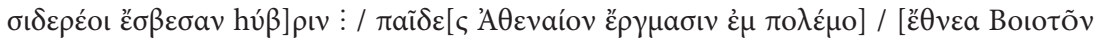

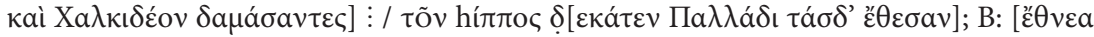

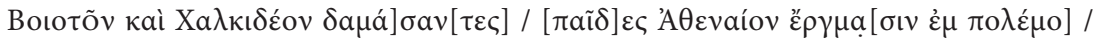

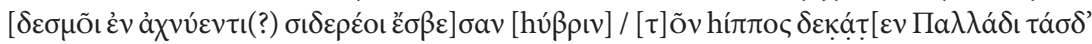

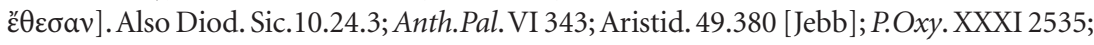
Const. Porph. De Sententiis 105 [p.299 Boissevain]. The monument seen by Herodotus (and also apparently Pausanias 1.28.2) was probably a replica, the Persians presumably having taken or demolished the original: Mattingly 1982: 383-84 suggests restoration in the 470s. Berti 2010 supports the old suggestion that the Battle of Oenophyta (in 457) was the occasion. Palaeography, in particular the appearance of three-bar sigma, inclined Raubitschek 1949: 203-5 no.173, to favor ca.456. I cannot see how this is any more likely an occasion than Athens's victory in 446/5. On this monument and the "Euripos epitaph" see Anderson 2003: 151-57.

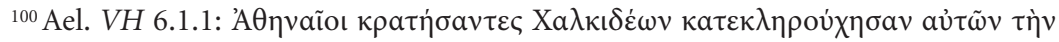

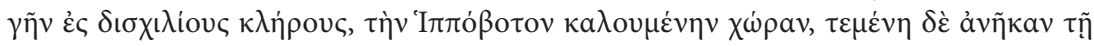

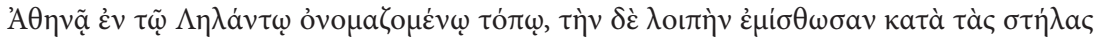

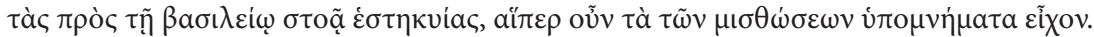

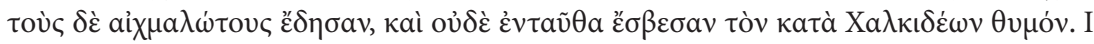
leave aside the well-covered ground of credibility of Aelian's account or whether he has conflated the episodes of 506 and 446/5; see recently Zelnick-Abramowitz 2004: 330-35.

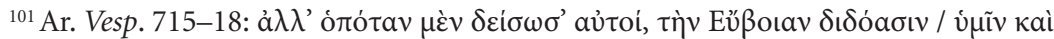

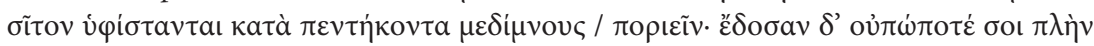

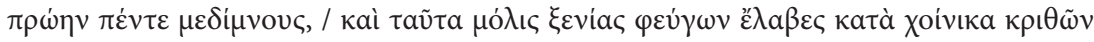
("Whenever they are afraid they give you Euboia and promise to furnish you grain in fifty-medimnoi increments. But so far they've given you nothing except, just now, five medimnoi — and that you just barely got, after escaping charges of being a foreigner-of barley, by the choinix"). 
for Athens that it may have been promised to be?), and that the requirement to prove citizenship went badly for thousands. ${ }^{102}$ Strepsiades observes, while surveying the earth, that Euboia was "stretched on the rack by us and Perikles." ${ }^{103}$ It is tempting to take this literally: by us, just recently, and by Perikles, back in $446 / 5$. In any case, the diachronic perspective is clear. It would be one thing for Aristophanes to make hay out of the recent campaign, but to do so in a way that so powerfully looks back to the revolt of $446 / 5$ suggests that recent events were regarded as both non-trivial and bound up in the prior military action-like an American observing the United States' "victory" in Operation Iraqi Freedom by joking about its "victory" in Operation Desert Storm.

This later Euboian campaign took place in a period in which Athens's extension of ateleia seems to have become more common, or at least more visible to us. In 424/3 Athens decreed honors, including ateleia, for Potamadoros and his son Eurytion, ${ }^{104}$ who are thought to have been among the democrats just exiled from Orchomenos (Thuc. 4.76.3). In this same period Athens seems to have granted Proxenides of Knidos immunity from "the other tele" but not from what the Knidians pay in tribute, ${ }^{105}$ and Mattingly speculates that the Boiotian exiles recognized in $I G \mathrm{I}^{3} 72$ "were probably given as wide a form of

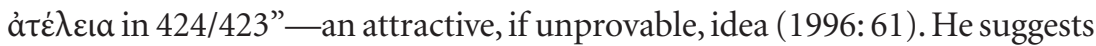
even that some of these privileged exiles may have taken the opportunity to settle in Euboia. It was perhaps in 424/3 that Athens honored Herakleides of

${ }^{102}$ FGrH 328 F119 [ $\Sigma$ Ar. Vesp. 718].

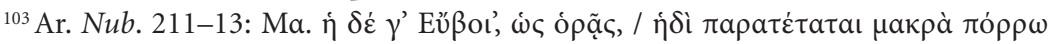

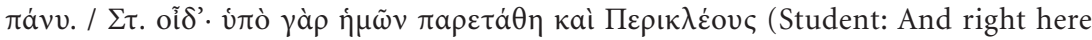
Euboia, as you see, is stretched out quite far. Strepsiades: I know, for it was stretched out

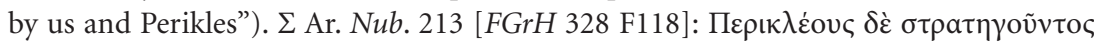

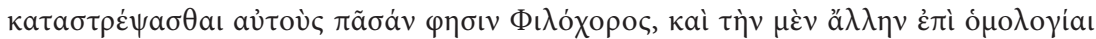

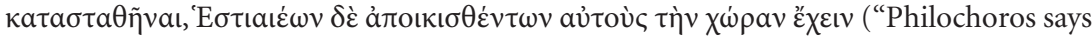
that when Perikles was strategos they overran the whole island, and that while the rest was arranged by agreement, they took the territory of Histiaia after it was colonized"). The scholiast's phrase closely resembles Thuc. 1.114.3 (n92 above).

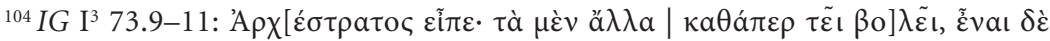

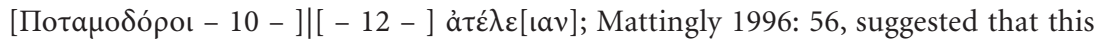
Archestratos may be the same as the man who proposed the rider at $I G \mathrm{I}^{3} 40.70-79$.

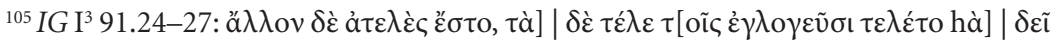

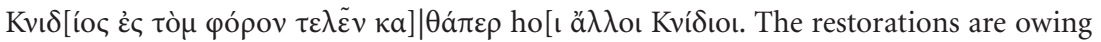
to Meritt 1939: 65-69, and are based on sense rather than exact parallels (69). Walbank 1978: 346 no.64 finds them convincing. No one seems to have challenged them. Matthaiou 2010: 18-19 notes that many texts in $I G \mathrm{I}^{3}$ are "over-restored." 
Klazomenai with ateleia.$^{106}$ It is tempting to see in this approach to rewarding individuals and groups with honors that included some form of tax-immunity an early expression of what we find more often in the fourth century. One thing, at least, is clear: such rewards are sparsely attested in the fifth century and more common in the fourth so that the later the date of the decree on Chalkis the less exceptional its approach to ateleia for aliens.

And it does make sense already, I suggest, in the economic and political landscape of the 420s. Christ has suggested that the antidosis mechanism, which we might think of as conferring court-ordered exemptions, emerged some time between the 450s and 430s; the procedure seems mature by the 420 s and cannot have functioned as we know it before the emergence of the dikasteria (1996: 159-60). This introduction of a formal mechanism by which exemptions might be claimed and substitutions proposed may have been an attempt, Christ suggests, to prevent wealthy elites from securing unfair exemptions for themselves and their friends. We cannot know for certain, but this same period saw increasing pressure on elite wealth elsewhere in the "tax" system: however we understand the famously ambiguous clause of Thucydides, it does not seem likely that Athens introduced eisphora much —if at all—before 428. ${ }^{107}$ In this period, Aristophanes could have the demagogue Kleon threaten to ruin a man by putting him down for eisphora, the so-called Old Oligarch could bemoan courts clogged with challenges to liturgical liability, and not much later Ischomachos could be said to have joked to Socrates that no one ever called him kalos k'agathos when challenging him to antidosis. ${ }^{108}$ Athens was honing its controls on access to elite wealth, through the popular courts, and devising new tougher means of extracting revenues, which were not open to court-sanctioned exemption. It was also a period in which complaints about these developments seem to have become more public, more vocal. This is

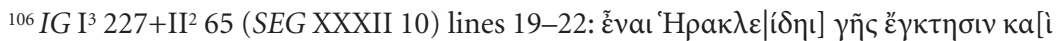

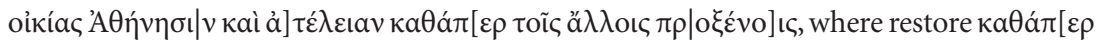

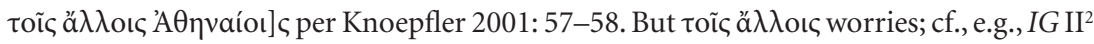

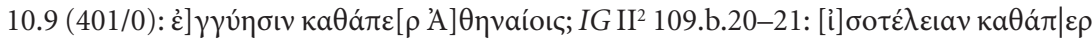

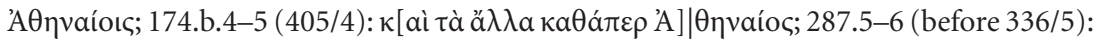

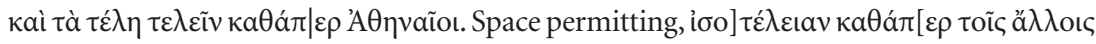

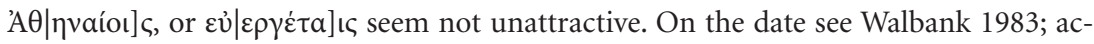
cepted by Reiter 1991: no.43. But for doubts see Mattingly 1996: 523-24 with citations; Harris 1999; Culasso Gastaldi 2004: 47-54.

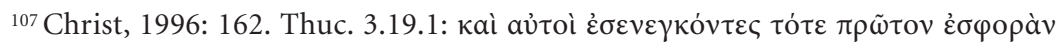

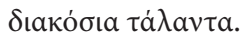

${ }^{108}$ Ar. Eq. 912-26; Xen. [Ath. pol.] 3.4; Xen. Oec. 7.3. 
nothing new, but a familiar story of waxing popular power in the 420 s, rooted at least partly in judicial control.

The decree on Chalkis fits nicely into this well known narrative. Ostwald has rightly called attention to its emphasis on "the Athenian people" (2002: 137). Under the decree's terms Athenians swore to punish no Chalkidian with exile, devastation, disfranchisement, exile, arrest, execution, or confiscation,

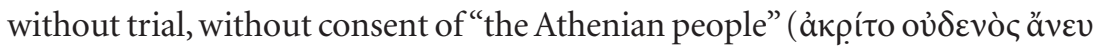

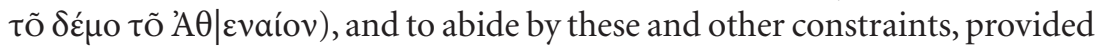
that Chalkidians obey "the Athenian people" (4-16). The Chalkidians were to swear not to revolt from "the Athenian people" (21-22), to aid and defend "the Athenian people" if anyone injures "the Athenian people" (29-31), and to obey "the Athenian people" (31-32). Antikles' provisions on aliens at Chalkis, moreover, excepted those who had been granted ateleia "by the Athenian people" (54-55). Now, while the Chalkidians were also to denounce revolutionaries "to the Athenians" (24-25) and pay "to the Athenians" whatever tribute they persuaded "the Athenians" to accept (25-27), the emphasis on allegiance and obligation to the demos per se is striking, perhaps even pushy. ${ }^{109}$

The courts and the people were the backbone of Athenian democratic power, so that the vow to abstain from punishments without trial, ${ }^{110}$ "without consent of the demos," has the ring of a slogan. ${ }^{111}$ The injunction against

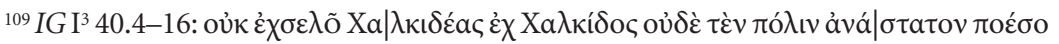

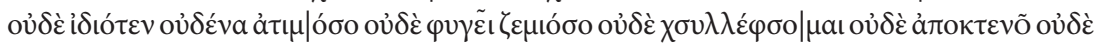

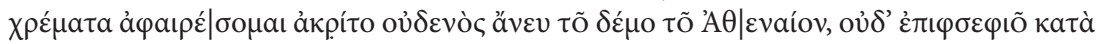

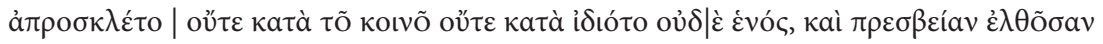

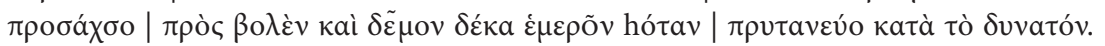

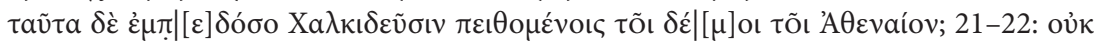

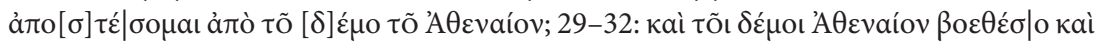

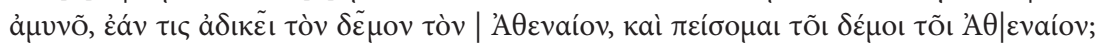

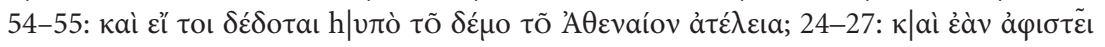

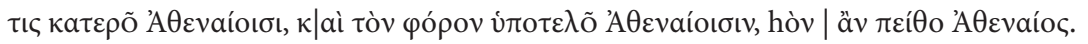

${ }^{110}$ The injunction against execution without trial seems also to have appeared in the bouleutic oath, [Andoc.] 4.3, some core of which likely comes from 501/0, as Ath. Pol. 22.3 gives; but this particular provision is generally held to have followed the coup of 403;

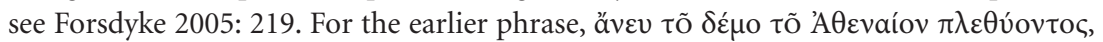
found at $I G \mathrm{I}^{3} 105.34-35,35,40-41$, which belongs to the period of Athens's "codification" of laws, but preserves regulations on the boule generally thought to belong to the early decades of the democracy, see Ryan 1994. For discussion see Ostwald 1986: 31-40.

${ }^{111}$ The two notes are perhaps sounded together elsewhere in Attic epigraphy in a heavily restored treaty between Athens and Siphnos, from the mid fourth century (Agora XVI

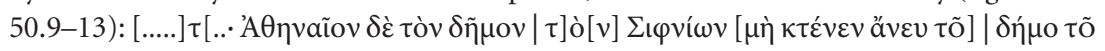

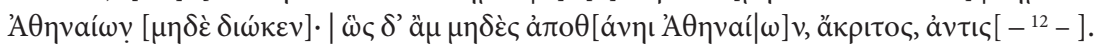


punishment without consent of the Athenian people appears in two Athenian proxeny decrees of the 420s. ${ }^{112}$ Moreover, when just a few years later the Mytilenian Euxitheos stood trial at Athens for a homicide alleged to have been committed abroad he strikes a similar chord. He reminded the jury that "not even a polis can punish a man with death without the consent of the Athenians" 113 and that "if it is possible for a slave to testify against a free man in a homicide trial, and for a master-if he decides to- to sue on behalf of his slave, and if there can be a jury vote, just the same, for one who has killed a slave and one who has killed a free man, then it was surely reasonable that there be a jury vote concerning him [a slave witness] as well, and that he not

It is often suggested, e.g., Forsdyke 2005: 213-14, and Ryan 1994: 125, that both ảkpíto

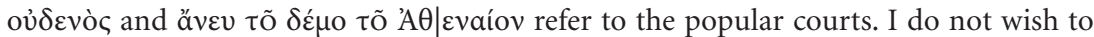
claim anything broad about the semantic overlap of demos, ekklesia, and dikasterion; see, e.g., Hansen 1983 [=GRBS 19 (1978) 127-46] and 1989 [=C\&M 40 (1989) 101-6]. But I am inclined to agree with Blanshard 2004: 31-34, esp.32, on the "gap" between jury and demos that this text suggests. The provision cannot have barred $\mathrm{X}, \mathrm{Y}$, and $\mathrm{Z}$, "without trial, i.e., without consent of the popular courts." As Blanshard observes, the one was not a gloss on the other. Furthermore, unless we regard ảkpíto oủ $\delta \varepsilon v o ̀ \varsigma$ as applying only to the immediately preceding promise not to seize a person's assets (8-9), which scarcely seems likely, then one of the actions Athenians swore to forego "without trial, without consent of the people" was civic devastation (5-6), which Athenian juries did not impose. The Greek simply insisted that extra-judicial punishment could not be imposed without consent of

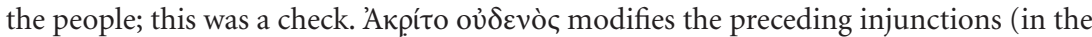

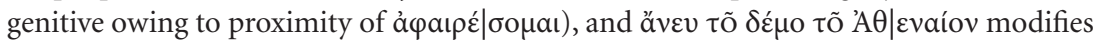
the union set. Any punishment that was not sanctioned by the courts would have to be approved by the people, which must mean the popular assembly. When the speaker of Lys. 22 observed that some members of the boule recommended remanding the sitopolai to the Eleven for execution "without trial," but that he preferred a jury trial "in accordance with the law," he was not, I suggest, stating that a jury trial was compelled by law (and thus that execution without one was illegal), but that he preferred to pursue one, as allowed by the law; he was boasting moderation, not the avoidance of illegality (22.2); Carawan 1984: 118 argues that by the second half of the fourth century such executions were illegal, "a familiar anachronism, still on the books, but noteworthy only as a legal curiosity" (121). True or not, that was decades after the decree on Chalkis.

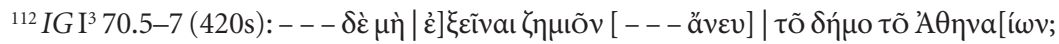

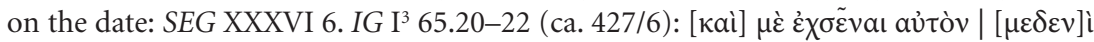

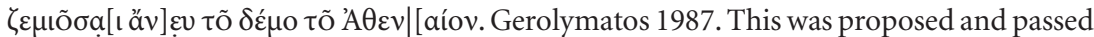

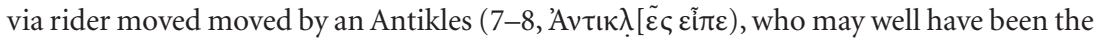
same man who proposed the second decree on Chalkis (IG I3 40.40): Mattingly 1996: 56.

${ }^{113}$ For a putative generic rule on this, as well as Archestratos's rider, see Balcer 1978: 102-18 and esp. 119-42. 
have been killed by you without a trial." 114 Now, Euxitheos did not claim the necessity of consent of "the people of Athens," but here was the son of a Mytilenian who was somehow involved in the recent oligarchical revolt, ${ }^{115}$ who was arguing that his trial before a popular court, rather than the more conservative Areopagos, was illegal and unfair (Antiph. 5.8-19)! Caution was in order. And so Antiphon had Euxitheos underscore the validity of Athens's jurisdictional claims, but also celebrate the power and importance of the popular courts with language that, to judge by its appearance in three contemporary decrees concerning Athens's obligations to its friends and allies (IG $\mathrm{I}^{3} 40,65$, 70), recalled a topical, current, popular catchphrase. He was not referring to the decree on Chalkis per se but to a wider cultural conversation of which it was a part. ${ }^{116}$ It is a telling contrast that around 453/2 Athens compelled Erythraians to swear allegiance under a different, less popular, banner. ${ }^{117}$

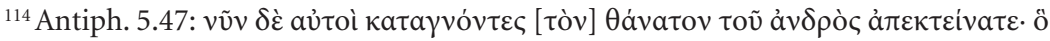

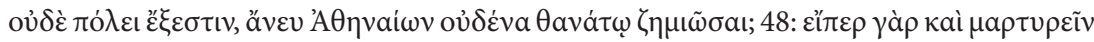

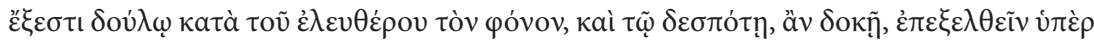

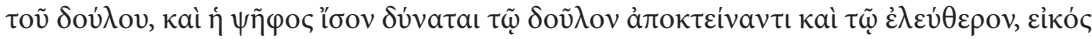

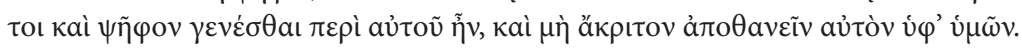

${ }^{115}$ Euxitheos protests that his father was not found to be involved in the revolt (Antiph. 5.77), that inasmuch as he had been involved he had acted under compulsion (79), and perhaps most enigmatically, that he had left Mytilene for Thrace not because of any wrongdoing but in order to avoid sycophants (78). True or not (we cannot know), this sounds like special pleading; $\chi \omega \rho о \varphi \iota \lambda \varepsilon \tilde{v} v$ was rare, this very passage earning comment by Poll. Onom. 13.

${ }^{116}$ In other, slightly later, contexts of political factionalism, the phrase seems to insist on reference to the assembly, or at least not to the courts: Rhodes and Osborne 17.3-11

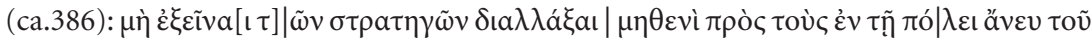

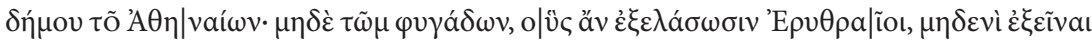

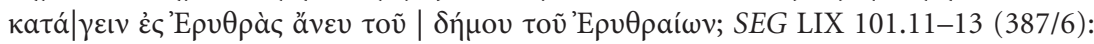

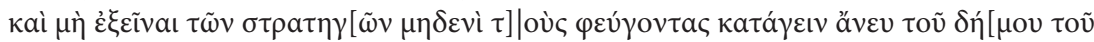

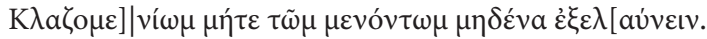

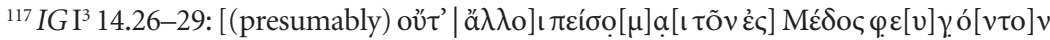

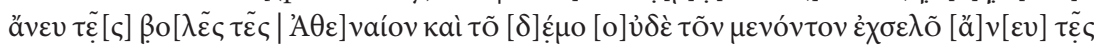

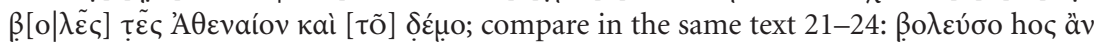

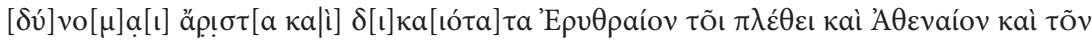

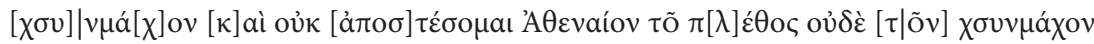

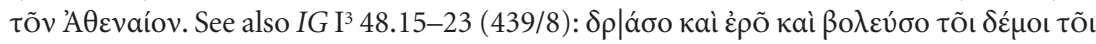

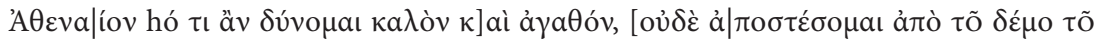

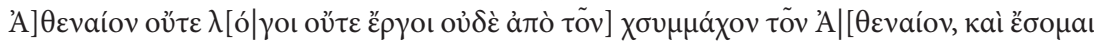

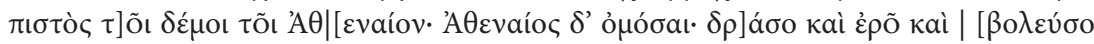

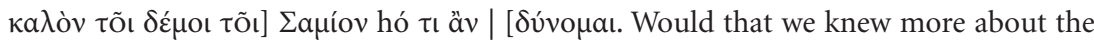


The 420s was a period in which questions of who was liable to Athenian taxation, who was not, and how one decided, were in the air, a hot topic; Athens was honoring friends with immunity, creating conditions under which its citizens could compete to shift burdens from themselves to their peers, and developing a new levy that was not subject to such agonistic trading. Complaints arose. Popular power was growing, thanks in large part to skillful use of the popular courts. ${ }^{118}$ The Athenian decree on Chalkis, with its emphasis on popular power and fair judicial process via the authority of the demos and dikasteria, with its legal innovation (Archestratos's rider) and its attention to rewarding and cultivating friends with thoughtfully framed immunities, is entirely at home in this period. It makes sense. Still, it is hard to infer motives from the content and tone of any decree, even where we think we know something about its proposer. But in $I G \mathrm{I}^{3} 40$ we have two decrees and one rider, and we know virtually nothing about their framers. As to the precise goals of the measures on liability and immunity at Chalkis, we can only speculate. In a climate of increased popular control over the assignment of liturgical duty, holders of immunities might find it difficult or embarrassing to insist upon their validity. Perhaps old elites and profit-minded metics who were reluctant to play by the new rules, or perhaps uneasy with the prospect of leaving their liability in the hands of a jury, found in recent events an opportunity to enact legislation that would allow them to quit the city and never have to pay taxes again. Or perhaps this was a democratic gambit meant to shed the most intransigent rich and pressure more moderate resisters to acquiesce, an

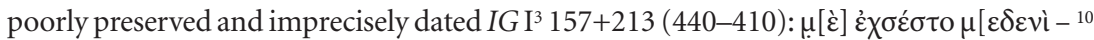

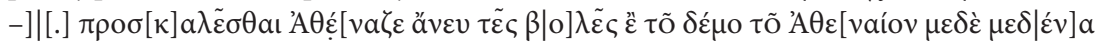
$\dot{\varepsilon} \gamma \mu \alpha \rho \rho \tau \rho \tilde{v} v$ aủंõ[ı. The pairing of boule and demos here in contexts quite similar to the one found in the decree on Chalkis, from but a few years earlier, makes it likely, I suggest, that the people in both formulas were the assembly, and not a jury court. See n111 above.

${ }^{118}$ The long, clearly complicated, and very badly preserved Athenian provisions for Histiaia ( $\left.I G \mathrm{I}^{3} 41\right)$ are challenging to square with historical circumstances of one period or another. It might be worth noting, however, that its numerous provisions concerning judicial and legal process would not be out of keeping with a date in the 420 s. Such a date would also suggest obvious meaning to the tantalizing bit preserved at line $38:---\delta \dot{\varepsilon}$

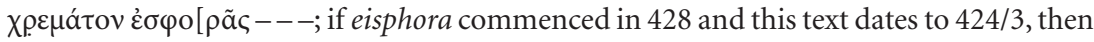
we need no other definition for this phrase; if the text belongs to 446/5, then we do not know what this "contribution of money" was, not that the phrase alone proves anything.

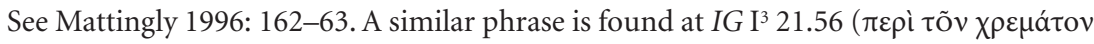
$\tau \tilde{\varepsilon} \varsigma \dot{\varepsilon} \sigma \varphi \circ \rho \tilde{a}$ [ $\varsigma$ ), for which Mattingly's later date 426/5 is now accepted: Rhodes 2008: 503; Papazarkadas 2009: 71-72. 
expression of a democratic ideology that applied to both citizens and metics: if you want to stay, you have to pay to play. Or something altogether different.

But whatever the precise political or economic purpose(s) of the clauses on taxation of aliens at Chalkis-and we may never know-they left Chalkis free to set its own tax policy, except in the case of individuals to whom Athens had already extended the privilege of ateleia, whether conditional on residency or not. They were a clear assertion of Athens's role as chief arbiter of honor: whomsoever Athens treats to immunity, so shall Chalkis. And so says the grammar. I urge that this interpretation is agreeable to a date of $424 / 3$. But whatever the date, the measure itself was a slap in the face, not a punch in the gut.

\section{WORKS CITED}

Anderson, G. 2003. The Athenian Experiment: Building an Imagined Political Community in Ancient Attica, 508-490 B.C. Ann Arbor: University of Michigan Press.

Badian, E. 1993. From Plataea to Potidaea: Studies in the History and Historiography of the Pentecontaetia. Baltimore: Johns Hopkins University Press.

Balcer, J. M. 1978. The Athenian Regulations for Chalkis: Studies in Athenian Imperial Law. Wiesbaden: Steiner.

Bengtson, H. 1975. Die Staatsverträge des Altertums II: Die Verträge der griechisch-römischen Welt von 700 bis 338 v. Chr. 2nd ed. Munich: Beck.

Berti, S. 2010. "La dedica degli Ateniesi per la vittoria su Beoti e Calcidesi del 506 a.C. (IG $I^{3}$ 501) e la data del suo ripristino." Aevum 84: 7-40.

Blanshard, A. J. L. 2004. "What Counts as the Demos? Some Notes on the Relationship between the Jury and 'The People' in Classical Athens." Phoenix 58: 28-48.

Brun, P. 2005. Impérialisme et démocratie à Athènes: Inscriptions de l'époque classique. Paris: Armand Colin.

Carawan, E. M. 1984. “Akriton Apokteinai: Execution without Trial in Fourth-Century Athens." GRBS 25: 111-21.

Cargill, J. 1995. Athenian Settlements of the Fourth Century B.C. Leiden: Brill.

Chankowski, V. 2007. "Les catégories du vocabulaire de la fiscalité dans les cités grecques." In Andreau, J. and Chankowski, V. eds. Vocabulaire et expression de l'économie dans le monde antique. Pessac: Ausonius: 299-331.

Christ, M. R. 1990. "Liturgy Avoidance and Antidosis in Classical Athens." TAPA 120: 147-69.

. 2006. The Bad Citizen in Classical Athens. Cambridge: Cambridge University Press.

.2007. "The Evolution of the Eisphora in Classical Athens." CQ 57: 53-69.

Cohen, E. E. 1992. Athenian Economy and Society: A Banking Perspective. Princeton: Princeton University Press.

Culasso Gastaldi, E. 2004. Le prossenie ateniesi del IV secolo a.C.: gli onorati asiatici. Alessandria: Edizioni dell'Orso. 
Dillon, M. and Garland, L. 2010. Ancient Greece: Social and Historical Documents from Archaic Times to the Death of Socrates (c. 800-399 BC). 3rd ed. London: Routledge.

Dover, K. J. 1978. “ $\triangle \mathrm{E}$ in the Khalkis Decree.” ZPE 30: 94.

Engen, D. T. 2010. Honor and Profit: Athenian Trade Policy and the Economy and Society of Greece, 415-307 B.C.E. Ann Arbor: University of Michigan Press.

Fornara, C. W. 1977. "IG I² 39.52-57 and the 'Popularity' of the Athenian Empire." ClAnt 10: $39-55$.

1983. Archaic Times to the End of the Peloponnesian War. 2nd ed. Cambridge: Cambridge University Press.

Forsdyke, S. 2005. Exile, Ostracism, and Democracy: The Politics of Expulsion in Ancient Greece. Princeton: Princeton University Press.

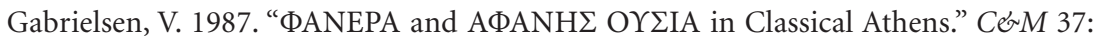
99-114.

1994. Financing the Athenian Fleet: Public Taxation and Social Relations. Baltimore: Johns Hopkins University Press.

Gagarin, M. 1997. Antiphon: The Speeches. Cambridge: Cambridge University Press.

Gauthier, P. 1971. "Les EENOI dans les textes athéniens de la seconde moitié du Ve siècle av. J.-C.” REG 84: 44-79.

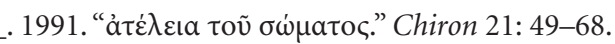

Gerolymatos, A. 1987. “A Note on Apollonophanes of Kolophon and $I G I^{3} .65$.” Euphrosyne 15: 227-33.

Giovannini, A. 2000. "Imposition et exemption fiscales des étrangers dans le règlement athénien sur Chalcis IG I3 40.” ZPE 133: 61-74.

Hagemajer Allen, K. 2003. "Intercultural Exchanges in Fourth-Century Attic Decrees." ClAnt 22: 199-250.

Hansen, M. H. 1983. The Athenian Ecclesia I: A Collection of Articles 1976-1983. Copenhagen: Museum Tusculanum. . 1989. The Athenian Ecclesia II: A Collection of Articles 1983-1989. Copenhagen: Museum Tusculanum.

Harris, E. M. 1999. "IG I 227 and the So-Called Peace of Epilykos." ZPE 126: 123-28.

Henry, A. S. 1979. “Athens and Chalcis: I.G.i² 39, Lines 52-57 Yet Again.” ZPE 35: 287-91. . 1983. Honours and Privileges in Athenian Decrees: The Principal Formulae of Athenian Honorary Decrees. Hildesheim: Olms.

Jameson, M. H. 2000-2003. “Athens and Phaselis, IG I 10 (EM 6918).” HOPO $14-16$ : 23-29.

Jones, C. P. 2003. “Epigraphica VI-VII.” ZPE 144: 157-63.

Kamen, D. 2013. Status in Classical Athens. Princeton: Princeton University Press.

Knoepfler, D. 2001. Décrets érétriens de proxénie et de citoyenneté. Lausanne: Editions Payot. Koch, C. 1991. Volksbeschlüsse in Seebundangelegenheiten: Das Verfahrensrecht Athens im Ersten attischen Seebund. Frankfurt am Main: Peter Lang.

Kremmydas, C. 2012. Commentary on Demosthenes Against Leptines. Oxford: Oxford University Press.

Lawton, C. 1992. "Sculptural and Epigraphical Restorations to Attic Documents." Hesperia 61: 239-51. 


\section{Clarendon.}

1995. Attic Document Reliefs: Art and Politics in Ancient Athens. Oxford:

Lewis, D. M. 1992. “The Thirty Years' Peace.” In Lewis, D. M. et al. eds. The Cambridge Ancient History, Second Edition: Volume V: The Fifth Century. Cambridge: Cambridge University Press: 121-46.

Lewis, N. 1960. “Leitourgia and Related Terms.” GRBS 3: 175-84.

. 1971. Greek Historical Documents: The Fifth Century B.C. Toronto: Hakkert.

Low, P. 2005. "Looking for the Language of Athenian Imperialism.” JHS 125: 93-111.

MacDowell, D. M. 2004. "Epikerdes of Kyrene and the Athenian Privilege of Ateleia." ZPE 150: 127-33.

Matthaiou, A. P. 2010. The Athenian Empire on Stone Revisited: David Lewis Lecture in Ancient History, Oxford 2009. Athens: Hellenike Epigraphike Hetaireia.

Mattingly, H. B. 1961. “Athens and Euboea.” JHS 81: 124-32.

. 1982. "The Athena Nike Temple Reconsidered." AJA 86: 381-85.

. 1992. "Epigraphy and the Athenian Empire." Historia 41: 129-38.

1996. The Athenian Empire Restored: Epigraphic and Historical Studies. Ann

Arbor: University of Michigan Press.

2002. "The Athenian Decree for Chalcis (IG I³.40)." CQ 52: 377-79.

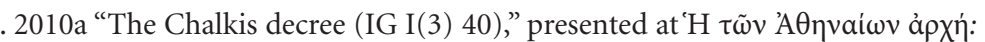

The Athenian Empire: Old and New Problems, British School in Athens, May 2010: http://www.bsa.ac.uk/doc_store/FrontOffice/FRO2010_29.pdf

. 2010b "Methodology in Fifth-Century Epigraphy." In Reger, G., Ryan, F. X., and Winters, T. F. eds. Studies in Greek Epigraphy and History in Honor of Stephen V. Tracy. Pessac: Ausonius. 97-105.

Meritt, B. D. 1939. “Greek Inscriptions (14-27).” Hesperia 8: 48-82.

Meyer, E. 1899. Forschungen zur alten Geschichte II. Halle: Niemeyer.

Moggi, M. 1979. "L'eisphorà dei coloni ateniesi a Potidea ([Aristot.] “Oec.” 2,2,5 [1347a].” QUCC 1: 137-42.

Moreno, A. 2007. Feeding the Athenian Democracy: The Athenian Grain Supply in the Fifth and Fourth Centuries BC. Oxford: Oxford University Press.

Morrison, W. S. 2003. "Property Records for Athenian Cleruchs or Colonists?: Notes on IG I3 420.” ZPE 145: 109-13.

Ostwald, M. 1986. From Popular Sovereignty to the Sovereignty of Law: Law, Society, and Politics in Fifth-Century Athens. Berkeley: University of California Press.

. 2002. "Athens and Chalkis: A Study in Imperial Control." JHS 122: 134-43.

Papazarkadas, N. 2009. "Epigraphy and the Athenian Empire: Reshuffling the Chronological Cards." In Ma, J., Papazarkadas, N., and Parker, R. eds. Interpreting the Athenian Empire: New Essays. London: Duckworth. 67-88.

Pébarthe, C. 1999. “Thasos, l'empire d'Athènes et les emporia de Thrace.” ZPE 126: 131-54. . 2000. "Fiscalité, empire athénien et écriture: Retour sur les causes de la guerre du Péloponnèse." ZPE 129: 47-76.

2005. "La perception des droits de passage à Chalcis (IG I3 40, 446 A.C.)." Historia 54: 84-92.

2006. Cité, démocratie et écriture : histoire de l'alphabétisation d'Athènes à l'époque classique. Paris: De Boccard. 
Raubitschek, A. E. and Jeffery, L. H. 1949. Dedications from the Athenian Akropolis: A Catalogue of the Inscriptions of the Sixth and Fifth Centuries B.C. Cambridge, MA: Archaeological Institute of America.

Reiter, H. A. 1991. Athen und die Poleis des Delisch-Attischen Seebundes: die Proxenoi und Euergetai des attischen Demos in den Poleis des Delisch-Attischen Seebundes im Licht der attischen Proxenie- und Euergesiebeschlüsse des 5. Jahrhunderts v. Chr. Regensburg: Roderer.

Rhodes, P. J. 1993. A Commentary on the Aristotelian Athenaion Politeia. Oxford: Clarendon Press.

. 2008. "After the Three-Bar Sigma Controversy: The History of Athenian Imperialism Reassessed.” CQ 58: 501-6.

Rubinstein, L. 2009. "Ateleia Grants and their Enforcement in the Classical and Early Hellenistic Periods.” In Mitchell, L. G. and Rubinstein, L. eds. Greek History and Epigraphy: Essays in Honour of P. J. Rhodes. Swansea: Classical Press of Wales.115-43. Ryan, F. X. 1994. “The Original Date of the $\delta \tilde{\eta} \mu \circ \varsigma \pi \lambda \eta \theta \dot{\omega} \omega v$ Provisions of $I G \mathrm{I}^{3} 105$. ” JHS 114: $120-34$.

Schweigert, E. 1937. "Inscriptions in the Epigraphical Museum." Hesperia 6: 317-32.

Slings, S. R. 1977. “Athenian Ateleia in I. G. I 39." ZPE 25: 277-79.

Smart, J. D. 1977. "IG I² 39: 'Aliens' in Chalcis." ZPE 24: 231-32.

Thomsen, R. 1964. Eisphora: A Study of Direct Taxation in Ancient Athens. Copenhagen: Gyldendal.

van Groningen, B. A. 1933. Aristote: Le second livre de l'Économique. Leiden: Sijthoff. Vinogradov, Y. G. 1973. “Once More on the Chalkidian Psephism (IG I² 39).” VDI 1: 105-23. von Stern, E. 1916. “Zum athenischen Volksbeschluss über Chalkis.” Hermes 51: 630-32. Walbank, M. B. 1978. Athenian Proxenies of the Fifth Century B.C. Toronto: Samuel-Stevens. . 1983. "Herakleides of Klazomenai: A New Join at the Epigraphical Museum."

ZPE 51: 183-84.

Whitehead, D. 1976. “IG I² 39: 'Aliens' in Chalcis and Athenian Imperialism." ZPE 21: 251-59.

\section{Society.}

1977. The Ideology of the Athenian Metic. Cambridge: Cambridge Philological

Wilhelm, A. 1898. Review of C. Michel, Recueil fasc. I and II. GGA 160: 201-35 [=Kleine Schriften II.4 213-47]. 1942. “Attische Urkunden: V. Teil.” Sitz. Wien 220.5: 3-192 [=Akademieschriften I 619-808].

Wilson, P. 2000. The Athenian Institution of the Khoregia: The Chorus, the City and the Stage. Cambridge: Cambridge University Press.

Zelnick-Abramowitz, R. 2004. "Settlers and Dispossessed in the Athenian Empire." Mnemosyne 57: 325-45.

Zoeppfel, R. 2006. Aristoteles Oikonomika: Schriften zu Hauswirtschaft und Finanzwesen. Berlin: Akademie Verlag. 